\title{
Acid-Sensitive Surfactants Enhance the Delivery of Nucleic Acids
}

Joachim Justad Røise ${ }^{\mathrm{ab} \ddagger}$, Hesong Han ${ }^{\mathrm{b} \ddagger}$, Jie Li ${ }^{\mathrm{b}}$, D. Lucas Kerr ${ }^{\mathrm{ab}}$, Chung Taing ${ }^{\mathrm{ab}}$, Kamyar Behrouzi ${ }^{\mathrm{bc}}$, Maomao He ${ }^{\mathrm{b}}$, Emily Ruan ${ }^{\mathrm{ad}}$, Lienna Y. Chan ${ }^{\mathrm{b}}$, Eli M. Espinoza ${ }^{\mathrm{b}}$, Sören Reinhard ${ }^{\mathrm{b}}$, Kanav Thakker ${ }^{\mathrm{d}}$, Justin Kwon $^{\text {b }}$, Mohammad R. K. Mofrad ${ }^{\text {bce }} \&$ Niren Murthy ${ }^{\text {bf* }}$

a) Department of Chemistry, University of California, Berkeley, Berkeley, CA 94720, USA

b) Department of Bioengineering, University of California, Berkeley, Berkeley, CA 94720, USA

c) Department of Mechanical Engineering, University of California, Berkeley, Berkeley, CA 94720, USA

d) Department of Chemical and Biomolecular Engineering, University of California, Berkeley, Berkeley, CA 94720, USA

e) Molecular Biophysics and Integrative Bioimaging Division, Lawrence Berkeley National Lab, Berkeley, CA 94720

f) Innovative Genomics Institute (IGI), 2151 Berkeley Way, Berkeley, CA 94704, USA

$¥$ These authors contributed equally 


\section{Table of Contents}

1. $p H$-independent hemolytic efficiency of Ald-C8-PEG .................................................... 3

2. Molecular dynamics of CS12 ….................................................................................... 3

3. Measuring Copper content of CS12-DITFAA using ICP ................................................... 5

4. Nucleic acid retention gel .............................................................................................. 5

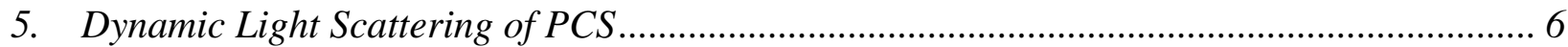

6. Dynamic Light Scattering of TCS ............................................................................... 7

7. Comparison of transfection agents ....................................................................................... 7

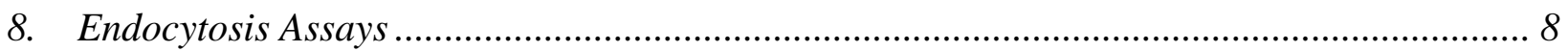

9. Flow Cytometry Histograms - Hela cells .......................................................................... 10

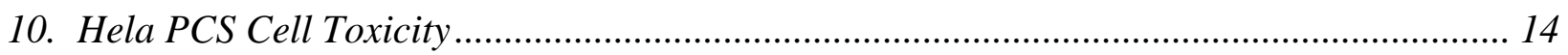

11. Flow Cytometry Histograms - HUVECs.......................................................................... 15

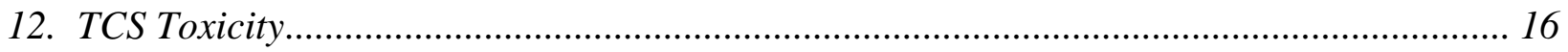

13. siRNA delivery by Lipofectamine ................................................................................. 16

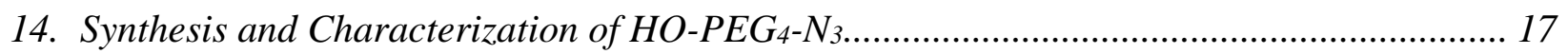

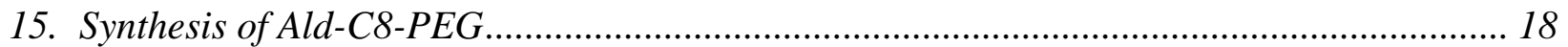

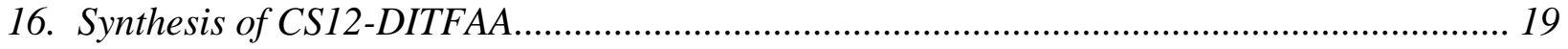

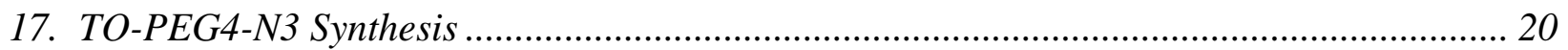

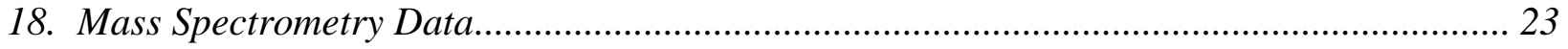

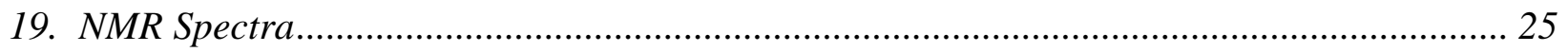

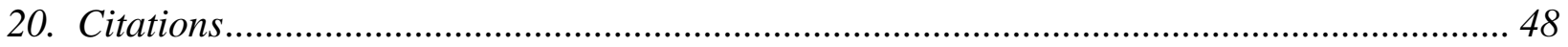




\section{1. pH-independent hemolytic efficiency of Ald-C8-PEG}

Ald-C8-PEG was synthesized (see Section 12) in order to confirm that the pH dependency of the caged surfactants is due to the caging PEG chains, as opposed to a $\mathrm{pH}$ dependent destabilization of RBC membranes. The hemolytic efficiency was measured at $\mathrm{pH} 7.5$ and 5.5.
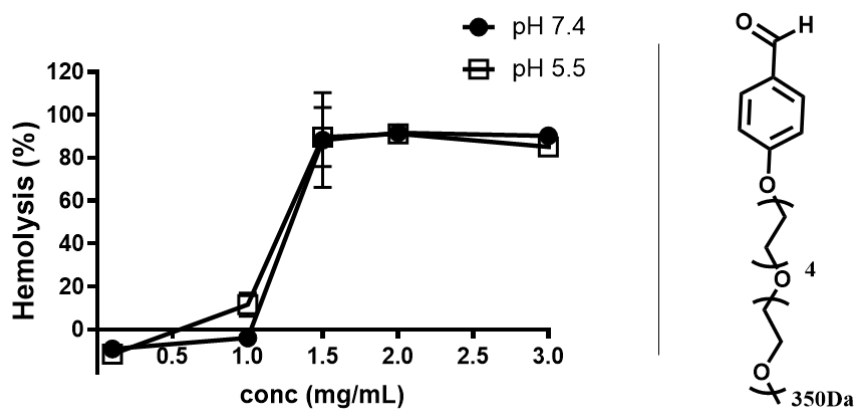

Figure S1: Ald-C8-PEG shows pH-independent hemolytic properties.

\section{Molecular dynamics of CS12}

Molecular Dynamic (MD) simulations were performed to determine the behavior of CS12 in physiological conditions. The chemical structure of $\mathbf{C S 1 2}$ was drawn using MARVIN ${ }^{1}$. As the proposed surfactant is new, we used the CHARMM forcefield database through the CGENFF interface to set the coefficients. ${ }^{2-5}$ To prepare input files for the CHARMM database, we used OPENBABEL and PyMOL software. ${ }^{6,7}$ After preparing the necessary input files for performing MD, we started to solvate CS12 inside the water box with a periodic boundary condition in the GROMACS environment. Then, we neutralized our box with $\mathrm{Na}^{+}$and $\mathrm{Cl}^{-}$and equilibrated our system at $300 \mathrm{~K}$ and 1 atm by using a modified Berendsen thermostat and Berendsen pressure coupling ${ }^{8}$. Finally, we let CS12 find its structure freely after $10 \mathrm{~ns}$, with 2 fs timesteps, under physiological conditions. It should be noted, that during $10 \mathrm{~ns}$ simulation, the pressure coupling was performed by using a Parrinello-Rahman barostat ${ }^{9}$, whereas the Berendsen method was used during equilibration, since the Berendsen method is useful for sudden pressure changes in the system ${ }^{8}$. Finally, we used $\mathrm{VMD}^{10}$ for molecular visualization and Adobe Photoshop for removing the background and making Figure S2. 
A)
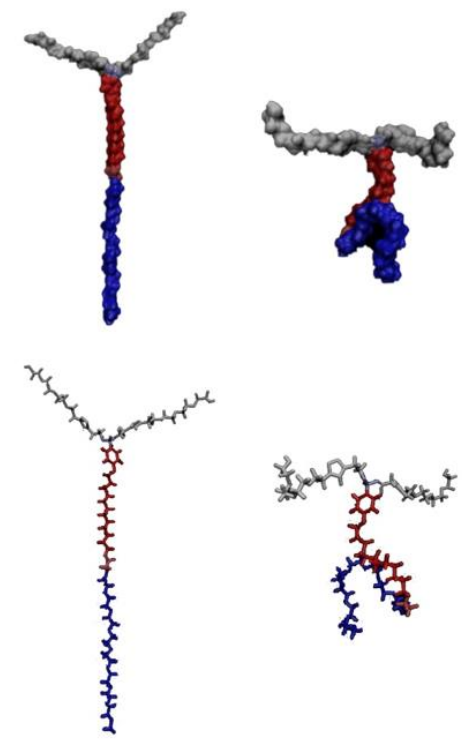

B)

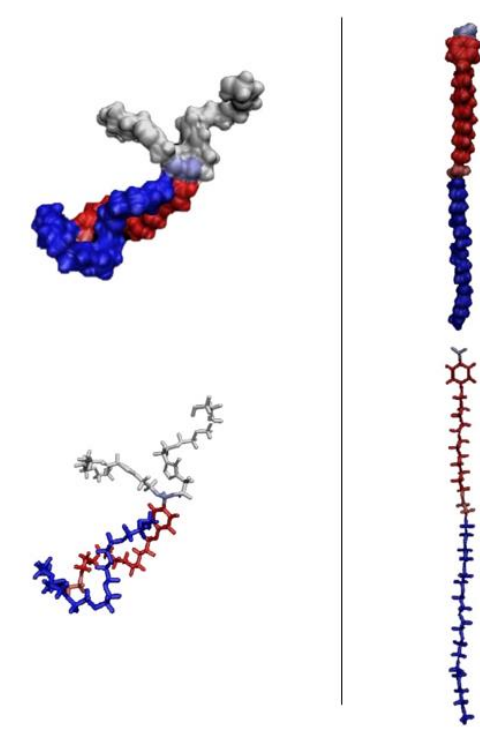

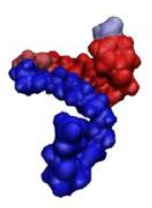
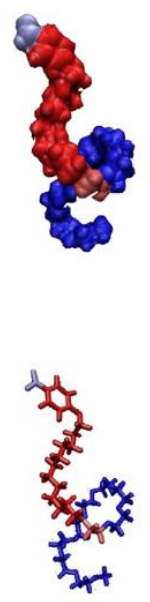

Figure S2: Molecular dynamics simulation to obtain molecular structures of CS12 in its intact and hydrolyzed form. (A) Molecular dynamics simulation of intact CS12 at to, after 1ns, and 10ns from left to right. (B) Structure of hydrolyzed CS12 at to, after Ins, and 10ns from left to right. At top, the surface structure of surfactant is shown and at bottom the licorice structure of caged surfactant has been depicted. Red refers to the hydrophobic domain and blue and white colors depict the hydrophilic (PEG) portions of the molecule. 


\section{Measuring Copper content of CS12-DITFAA using ICP}

Due to the cytotoxic nature of copper, the copper content of CS12DITFAA was by ICP-OES on a Perkin Elmer 5300 DV optical emission ICP instrument. CS12-DITFAA (1mg) was added to $2.5 \mathrm{~mL}$ of $2 \%$ nitric acid. A calibration curve (Figure S3) was established using copper standards ranging from 0.01 to $1000 \mathrm{mg} / \mathrm{L}$. When compared with the standard curve, the copper concentration was found to be $0.4 \mathrm{mg} / \mathrm{L}$ in CS12-DITFAA stock. This equals roughly 1ppm of copper in CS12-DITFAA. This value is near the limit of detection for copper on this instrument.

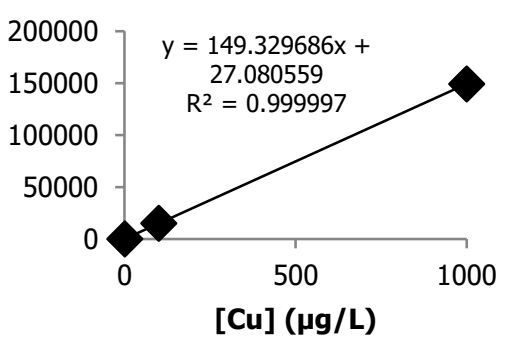

Figure S3: Calibration curve for Cu content.

\section{Nucleic acid retention gel}

mRNA retention by PCS was measured by adding PCS ( $6 \mu \mathrm{L}$, various concentrations) to mRNA (eGFP encoding, 600ng in $2 \mu \mathrm{L}$ ) followed by incubation for 1 hour before loading onto a $1 \%$ agarose gel. After running at $120 \mathrm{~V}$ for 30 minutes, the gel was imaged using a Bio-Rad ChemiDoc MP Imaging System using 1:1000 SYBR ${ }^{\mathrm{TM}}$ Safe (Thermo Fischer Scientific) as the intercalating imaging agent.

pDNA retention was measured similarly to mRNA retention on an agarose gel (1\%). eGFP-pDNA (250ng in $5 \mu \mathrm{L}$ ) was added to $5 \mathrm{uL}$ of $\mathbf{P C S}$ at various concentrations. After incubating for 1 hour at room temperature, the gel was run at $120 \mathrm{~V}$, and retention was quantified based on the dominant band of free pDNA (Figure S5). The efficiency was shown to be $50 \%$ retention at roughly $\mathrm{N} / \mathrm{P}=10$, which is similar to that of mRNA with a $50 \%$ retention efficiency at $\mathrm{N} / \mathrm{P}=11$. Full gels are shown in Figure S4 (mRNA) and Figure S5 (pDNA).

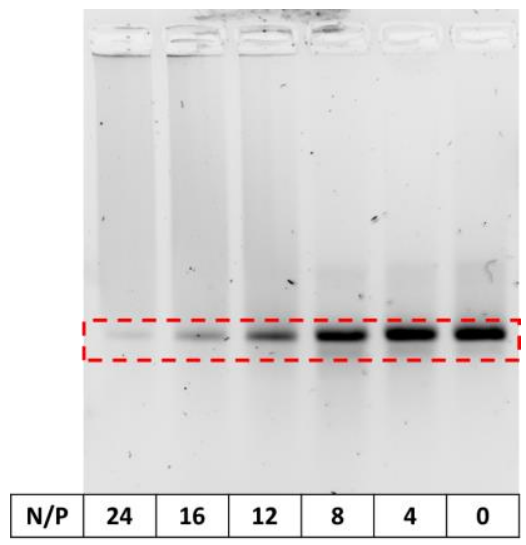

Figure S4: PCS retains mRNA on a gel. A) Agarose gel showing retention of mRNA upon addition of PCS. The ratio is given as $N / P$, referencing the amount of amine groups per phosphate group. 50\% retention is achieved at roughly $N / P=11$. 
A)

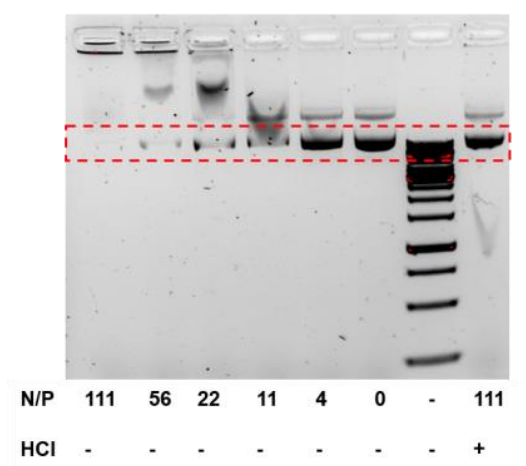

B)

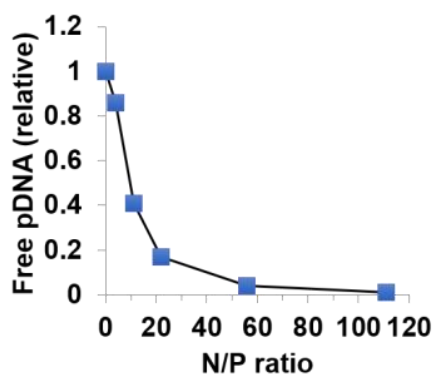

Figure S5: PCS retains pDNA on a gel. A) Agarose gel showing retention of pDNA. B) A plot showing degree of retention of pDNA. A retention efficiency of $50 \%$ is achieved around $\mathrm{N} / \mathrm{P}=10$. This is similar to the value found for $\mathrm{mRNA}$ of $\mathrm{N} / \mathrm{P}=11$.

\section{Dynamic Light Scattering of PCS}

DLS measurements were done by mixing $50 \mu \mathrm{L}(50 \mu \mathrm{g} / \mathrm{mL}$ in PBS) of nucleic acid (mRNA) with $7.5 \mu \mathrm{L}$ of PCS $(75 \mu \mathrm{g}$ in PBS). The mixture was incubated for 30 minutes before adding $1 \mu \mathrm{L}$ of Lipofectamine 2000. For the measurements of mRNA alone, as well as its complexes with PCS without Lipofectamine, the missing components were replaced with PBS. The measurements were done in triplicate. The complete data, including that of PCS alone, is given in Figure S6. Raw data and polydispersity indexes are given in Table S1.

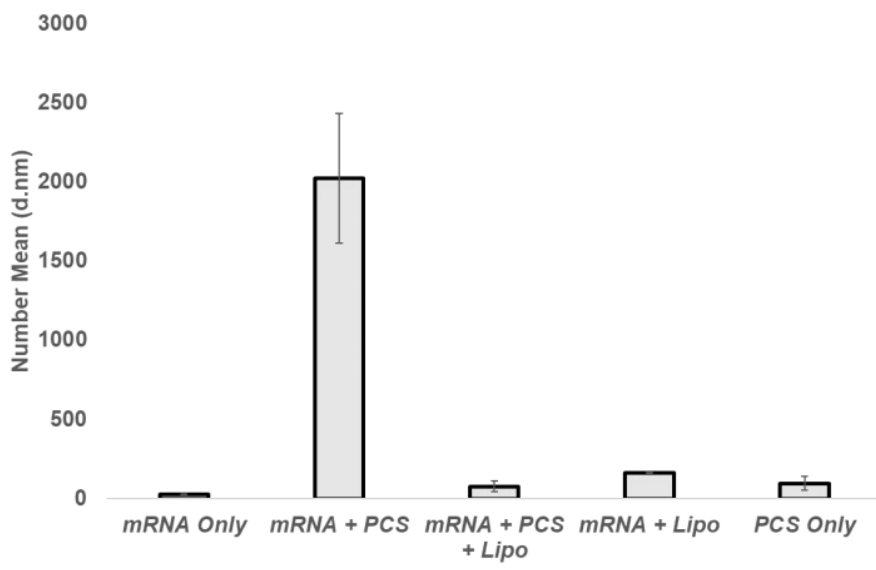

Figure S6: $D L S$ measurements of $m R N A, m R N A+P C S$, and $m R N A+P C S$ in the presence of Lipofectamine. A) The data shows a clear dependence of Lipofectamine to achieve efficient packing of nucleic acids, with average size of 77nm for mRNA/PCS/Lipo complexes, compared to $2023 \mathrm{~nm}$ and for $\mathrm{mRNA} / \mathrm{PCS}$ complexes. 
Table S1: Raw data for size and polydispersity indexes of $m R N A, m R N A+P C S, m R N A+P C S+L i p o, m R N A+L i p o$, and PCS only.

\begin{tabular}{|c|c|c|c|c|c|c|c|c|c|c|}
\hline & \multicolumn{2}{|c|}{ mRNA Only } & \multicolumn{2}{|c|}{ mRNA + PCS } & \multicolumn{2}{|c|}{ mRNA + PCS + Lipo } & \multicolumn{2}{|c|}{ mRNA + Lipo } & \multicolumn{2}{|c|}{ PCS Only } \\
\hline & $\begin{array}{l}\text { Number Mean } \\
\text { (d.nm) }\end{array}$ & PDI & $\begin{array}{l}\text { Number Mean } \\
\text { (d.nm) }\end{array}$ & PDI & $\begin{array}{l}\text { Number Mean } \\
\text { (d.nm) }\end{array}$ & PDI & Number Mean (d.nm) & PDI & Number Mean (d.nm) & PDI \\
\hline 1 & 24.59 & 0.819 & 2398 & 0.194 & 42.94 & 0.99 & 166 & 0.261 & 100.4 & 0.599 \\
\hline 2 & 28.44 & 0.811 & 1589 & 0.347 & 80.17 & 1 & 164.1 & 0.229 & 51.75 & 0.697 \\
\hline 3 & 26.15 & 0.516 & 2082 & 0.3 & 107.4 & 0.873 & 160.3 & 0.229 & 136.3 & 0.644 \\
\hline Ave & 26.39 & 0.72 & 2023.00 & 0.28 & 76.84 & 0.95 & 163.47 & 0.24 & 96.15 & 0.65 \\
\hline
\end{tabular}

\section{Dynamic Light Scattering of TCS}

DLS data (size and PDI) was collected as stated in the methods section of the main manuscript. The raw data is found in Table $\mathrm{S} 2$.

Table 2: Raw data for size and polydispersity indexes of siRNA, TCS, and siRNA+TCS.

\begin{tabular}{|c|c|c|c|c|c|c|}
\hline & \multirow{2}{*}{$\begin{array}{l}\text { siRNA } \\
\text { Number Mean } \\
\text { (d.nm) }\end{array}$} & \multirow[b]{2}{*}{ PDI } & \multirow{2}{*}{$\begin{array}{l}\text { TCS } \\
\text { Number Mean } \\
\text { (d.nm) }\end{array}$} & \multirow[b]{2}{*}{ PDI } & \multicolumn{2}{|c|}{ siRNA+TCS } \\
\hline & & & & & $\begin{array}{l}\text { Number Mean } \\
\text { (d.nm) }\end{array}$ & PDI \\
\hline 1 & 2.511 & 0.482 & 325.4 & 0.152 & 61.26 & 0.667 \\
\hline 2 & 3.322 & 0.462 & 248.3 & 0.527 & 48.34 & 0.679 \\
\hline 3 & 1.36 & 0.467 & 243.3 & 0.412 & 54.53 & 0.8 \\
\hline Ave & 2.40 & 0.47 & 272.33 & 0.36 & 54.71 & 0.72 \\
\hline
\end{tabular}

\section{Comparison of transfection agents}

In addition to Lipofectamine 2000, two additional transfection agents were investigated for their ability to transfect Hela cells (Figure S7). Transfections were performed by mixing together mRNA $(0.5 \mu \mathrm{g} / \mathrm{mL}$ final concentration), PCS ( $2 \mu \mathrm{g} / \mathrm{mL}$ final concentration) and X-tremeGene ${ }^{\mathrm{TM}} 360$ (low: $0.2 \mu \mathrm{L} / \mathrm{mL}$ ), TurboFect ${ }^{\mathrm{TM}}$ (low: $0.3 \mu \mathrm{L} / \mathrm{mL}$ ), or Lipofectamine 2000 (low: $0.2 \mu \mathrm{L} / \mathrm{mL}$ ). The complexes were added to Hela cells and incubated overnight in OptiMEM. This was compared to mRNA delivered at optimal delivery concentrations for X-tremeGene ${ }^{\mathrm{TM}} 360$ (high: $2 \mu \mathrm{L} / \mathrm{mL}$ ), TurboFect ${ }^{\mathrm{TM}}$ (high: $3 \mu \mathrm{L} / \mathrm{mL}$ ), and Lipofectamine 2000 (high: $2 \mu \mathrm{L} / \mathrm{mL}$ ). Neither $\mathrm{X}$-tremeGene ${ }^{\mathrm{TM}} 360$ or TurboFect ${ }^{\mathrm{TM}}$ achieved transfection levels comparable to that of Lipofectamine 2000, which saw roughly $80 \%$ transfection at optimal conditions. XtremeGene $^{\mathrm{TM}} 360$ was the only control transfection reagent with high levels of transfection, which gave roughly $30 \%$ transfection, while low levels of transfection agent with PCS only gave around 10\% transfection. For TurboFect ${ }^{\mathrm{TM}}$ these numbers were $40 \%$ for mRNA/transfection agent and $30 \%$ for mRNA/TurboFectTM/PCS. For flow cytometry histograms for the Lipofectamine data see Figure S9-S12. 


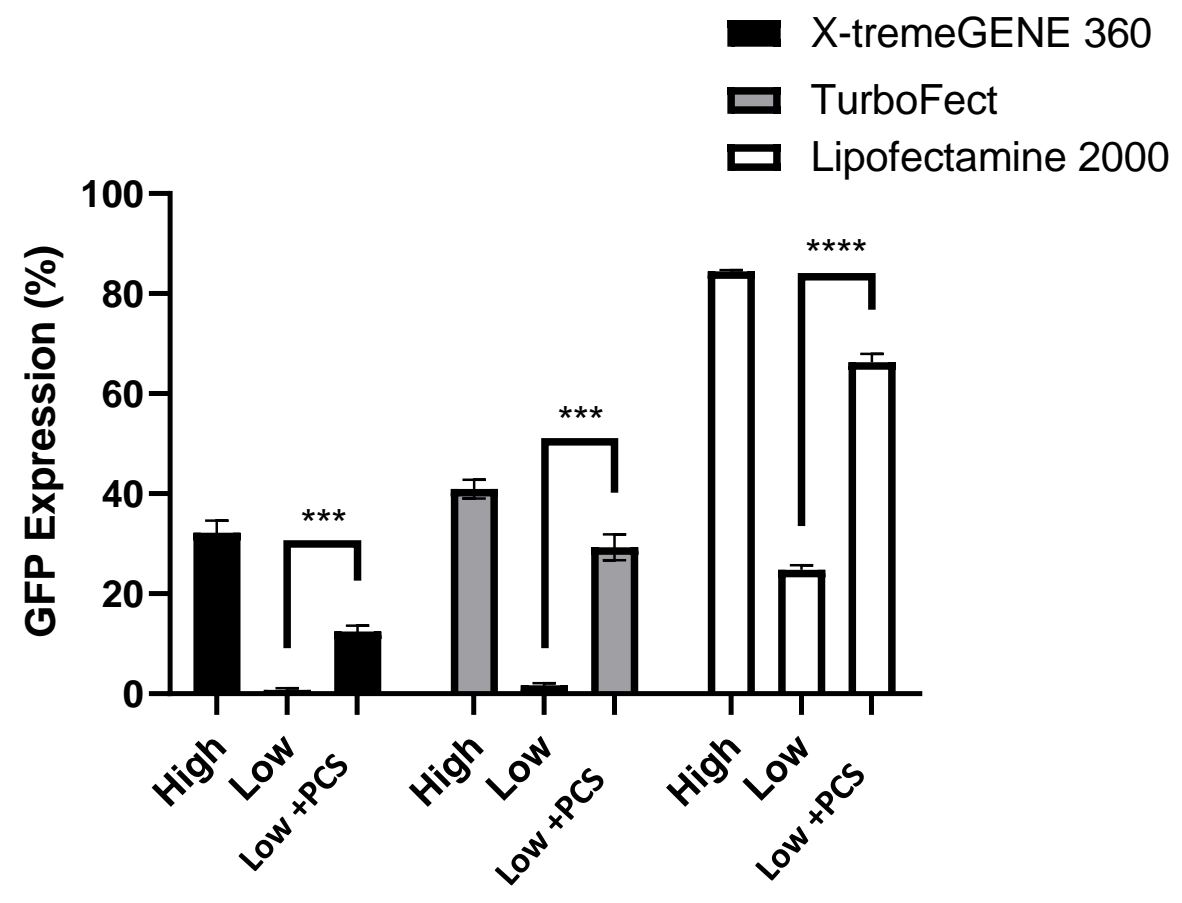

Figure S7: PCS increases the transfection rate of low levels of both $X$-tremeGene ${ }^{\mathrm{TM}} 360(0.2 \mu L / m L)$, TurboFect ${ }^{\mathrm{TM}}(0.3 \mu L / m L)$ and Lipofectamine $2000(0.2 \mu \mathrm{L} / \mathrm{mL})$ respectively. High levels of X-tremeGene ${ }^{\mathrm{TM}} 360$, TurboFect ${ }^{\mathrm{TM}}$, and Lipofectamine 2000 are $2 \mu \mathrm{L} / \mathrm{mL}, 3 \mu \mathrm{L} / \mathrm{mL}$ and $2 \mu \mathrm{L} / \mathrm{mL}$, respectively. $* * * P<0.001$, $* * * * P<0.0001$ (unpaired two-tailed $t$-test).

\section{Endocytosis Assays}

In order to investigate the mechanism of delivery for the mRNA/PCS/Lipo complexes, Hela cells were transfected in the presence of Wortmannin $(0.15 \mu \mathrm{g} / \mathrm{mL})$, Chlorpromazine $(1.5 \mu \mathrm{g} / \mathrm{mL})$, Genistein $(5 \mu \mathrm{g} / \mathrm{mL})$ and methyl- $\beta$-cyclodextrin $(7.5 \mathrm{mg} / \mathrm{mL})$. The inhibitors were incubated with Hela cells for $1 \mathrm{hr}$ before replacing the media. The mRNA/PCS/Lipo complexes were prepared by making a mixture of $2 \mu \mathrm{g} / \mathrm{mL}$ PCS, $500 \mathrm{ng} / \mathrm{mL} \mathrm{mRNA}$, and $2 \mu \mathrm{L} / \mathrm{mL}$ Lipofectamine 2000. The complex was incubated for 30 minutes before being added to cells and incubated overnight in OptiMEM. A control was done by using only Lipofectamine 2000 for delivery to see if there were any significant changes in delivery mechanism. The inhibitors used and their inhibiting pathways are as follows ${ }^{11}$ : (A) Wortmannin - Clathrin-dependent endocytosis (CDE), (B) Chlorpromazine - CDE, (C) Genistein - Clathrin-independent endocytosis (CIE), (D) Methyl- $\beta$ cyclodextrin (M $\beta \mathrm{CD})$ - Cholesterol-dependent uptake mechanisms (CDE and CIE at used concentrations ${ }^{12}$ ). The results below show that the uptake of the mRNA/PCS/Lipo-complexes happens by a similar mechanism to that of mRNA/Lipo complexes (Figure S8). The uptake is dependent on both Clathrindependent and Clathrin-independent endocytosis, as seen in the knock-down in the presence of chlorpromazine and genistein, respectively. This is in agreement with previously reported data. ${ }^{13}$ In addition, M $\beta C D$ caused a total knockdown in transfection efficiency, while maintaining cell viability (data not shown). At high concentrations, $\mathrm{M} \beta \mathrm{CD}$ can inhibit both Clathrin-dependent and independent pathways that 
are dependent on cholesterol, specifically those that involve lipid raft domains. ${ }^{14}$ These results confirm that endocytosis plays an important part in the delivery of mRNA complexed with PCS and Lipofectamine.

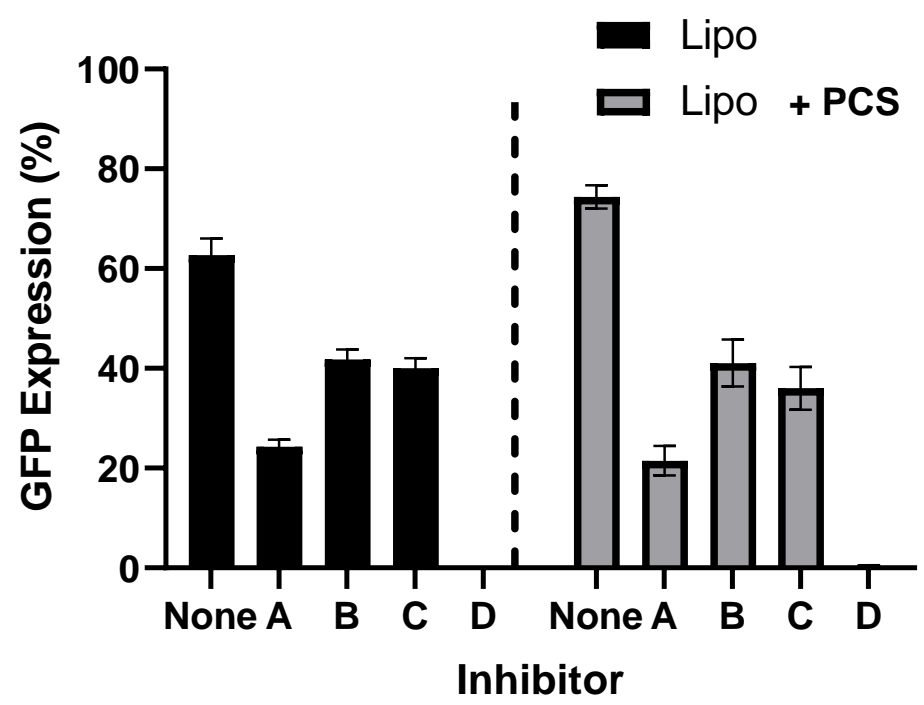

Figure S8: mRNA/PCS/Lipofectamine 2000 in endocytosed by a similar mechanism to Lipofectamine 2000-mediated delivery. The transfection efficiency is dependent on both Clathrin-dependent endocytosis (CDE) and Clathrin-independent endocytosis (CIE). The following inhibitors were incubated with Hela cells before transfection: $(A)$ Wortmannin - (CDE), (B) Chlorpromazine - CDE, (C) Genistein - (CIE), (D) Methyl- $\beta$-cyclodextrin $(M \beta C D)$ - Cholesterol-dependent uptake mechanisms (CDE and CIE at the concentrations used $\left.{ }^{\mathbf{1 2}}\right)$. 


\section{Flow Cytometry Histograms - Hela cells}
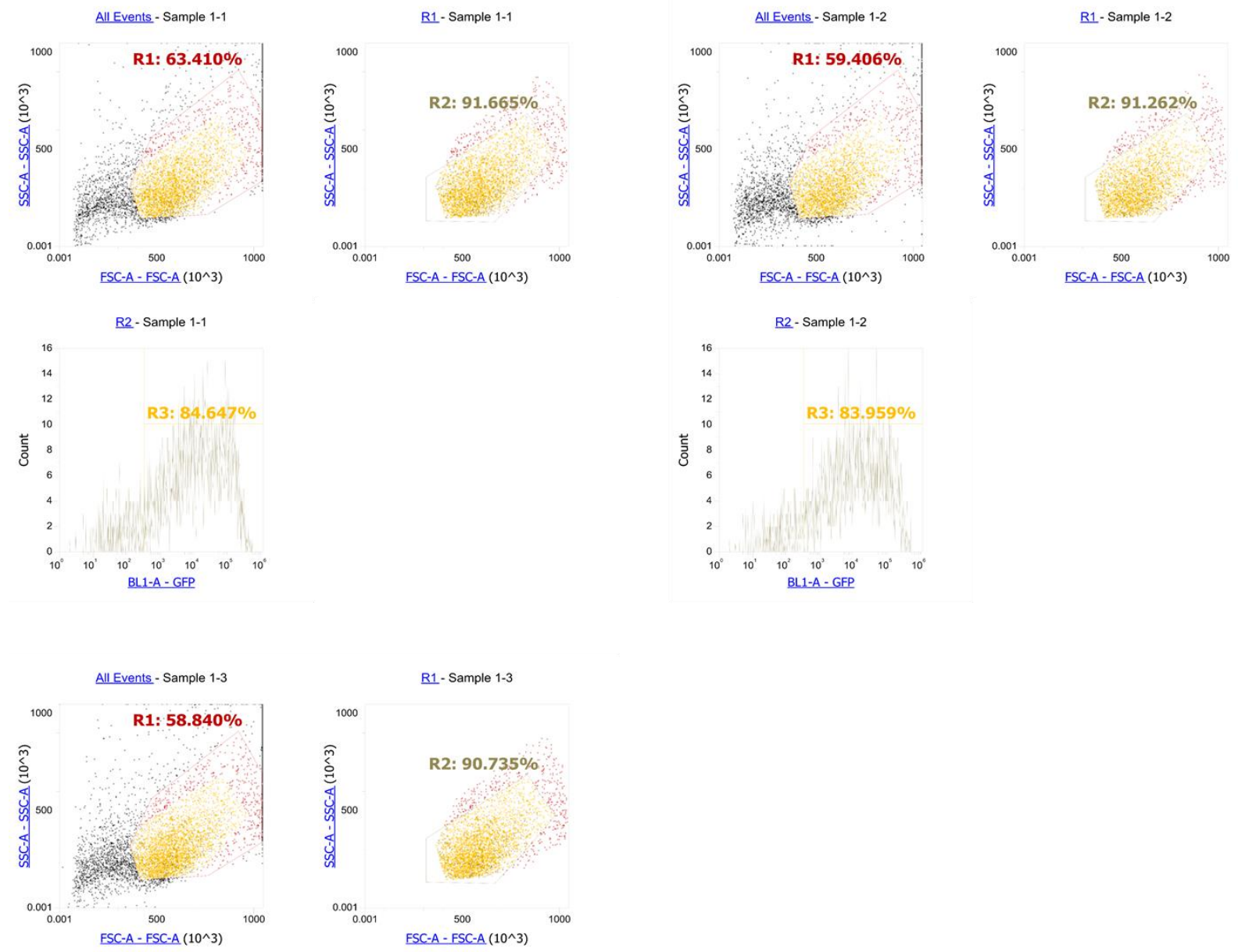

R1-Sample 1-3
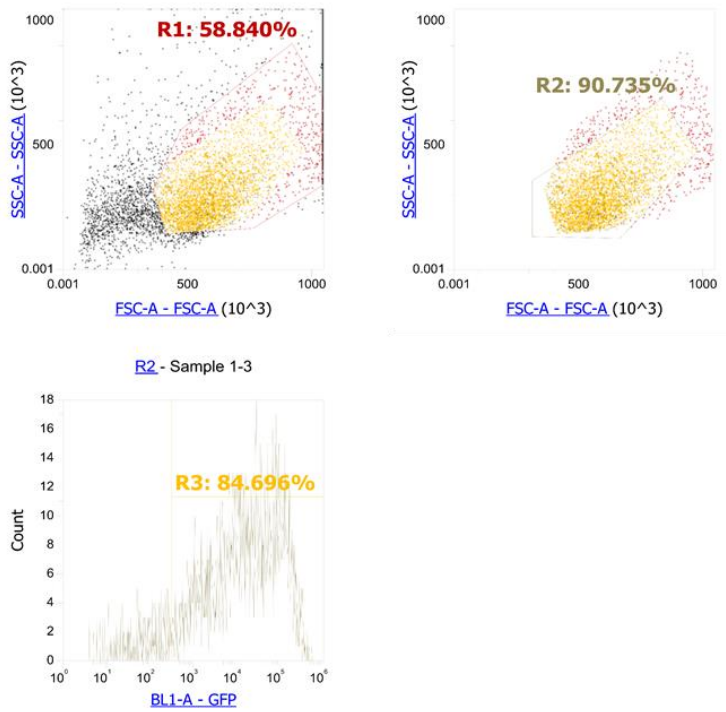

Figure S9: Flow Histograms for Hela cells transfected with GFP-expressing mRNA with Lipofectamine $(2 \mathrm{~mL} / \mathrm{mL})$. 

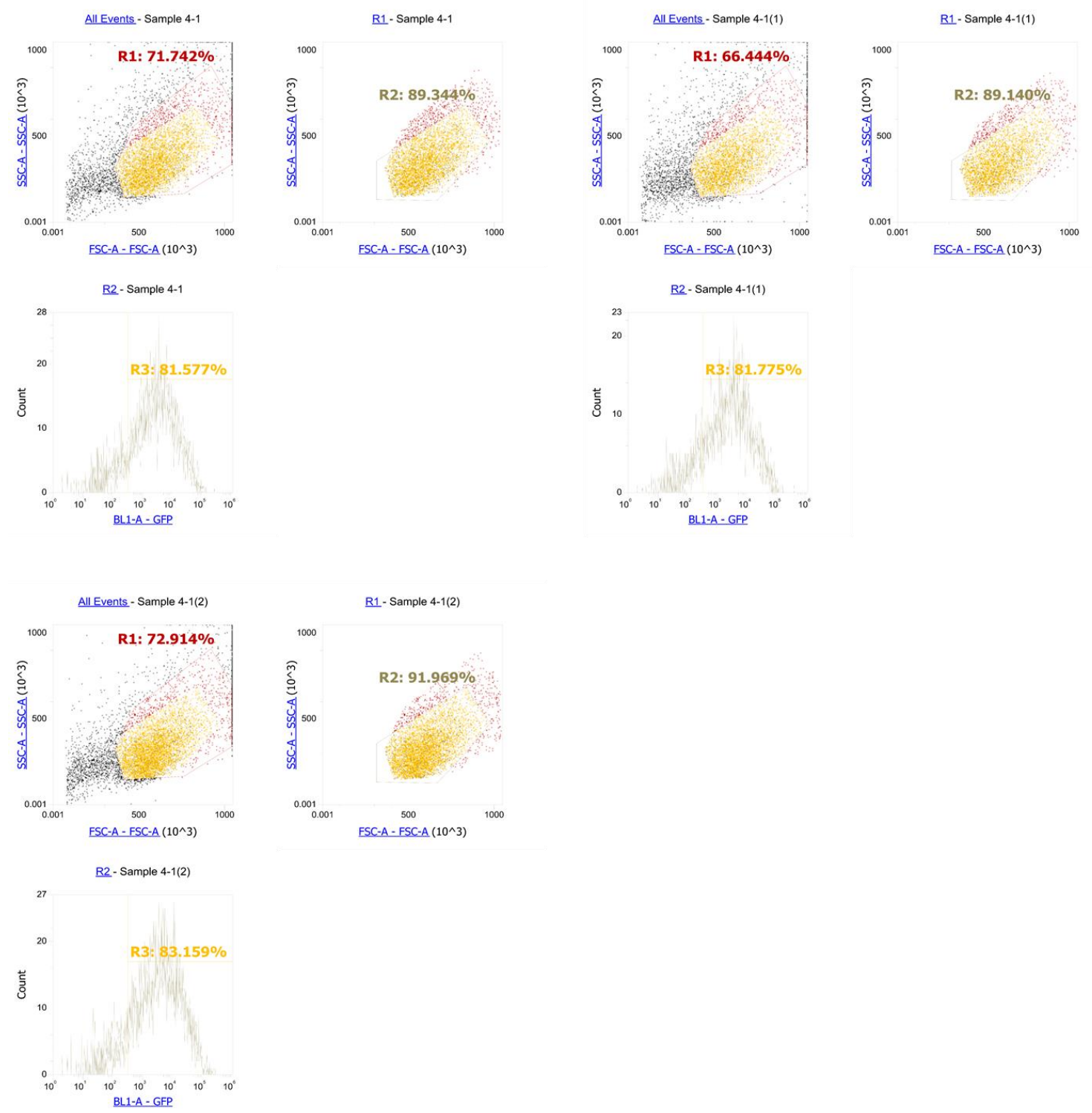

Figure S10: Flow Histograms for Hela cells transfected with GFP-expressing mRNA with Lipofectamine $(2 \mathrm{~mL} / \mathrm{mL})$ and PCS $(2 \mu \mathrm{g} / \mathrm{mL})$. 

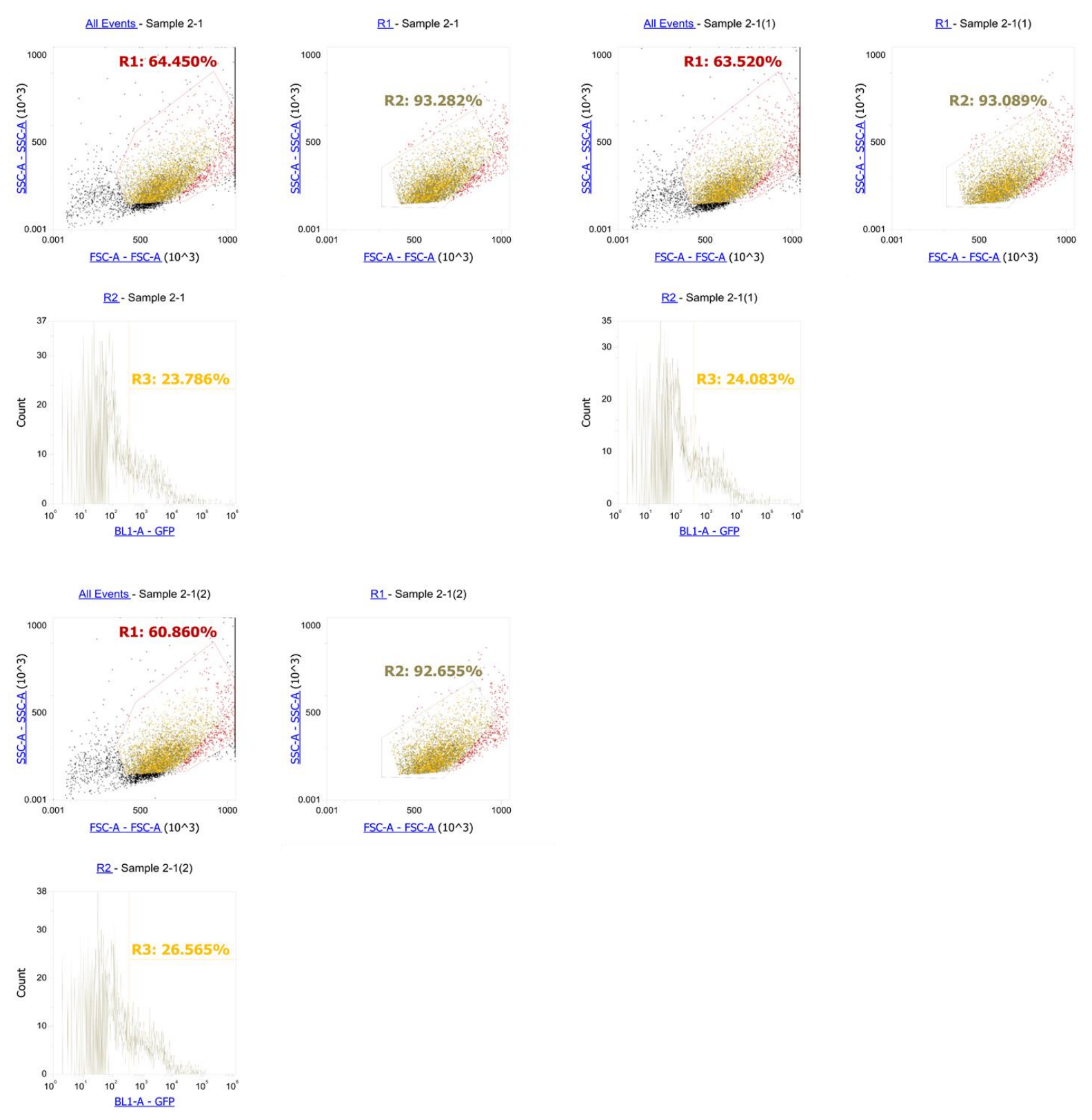

Figure S11: Histograms for Hela cells transfected with GFP-expressing mRNA with Lipofectamine $(0.2 \mu \mathrm{L} / \mathrm{mL})$. 

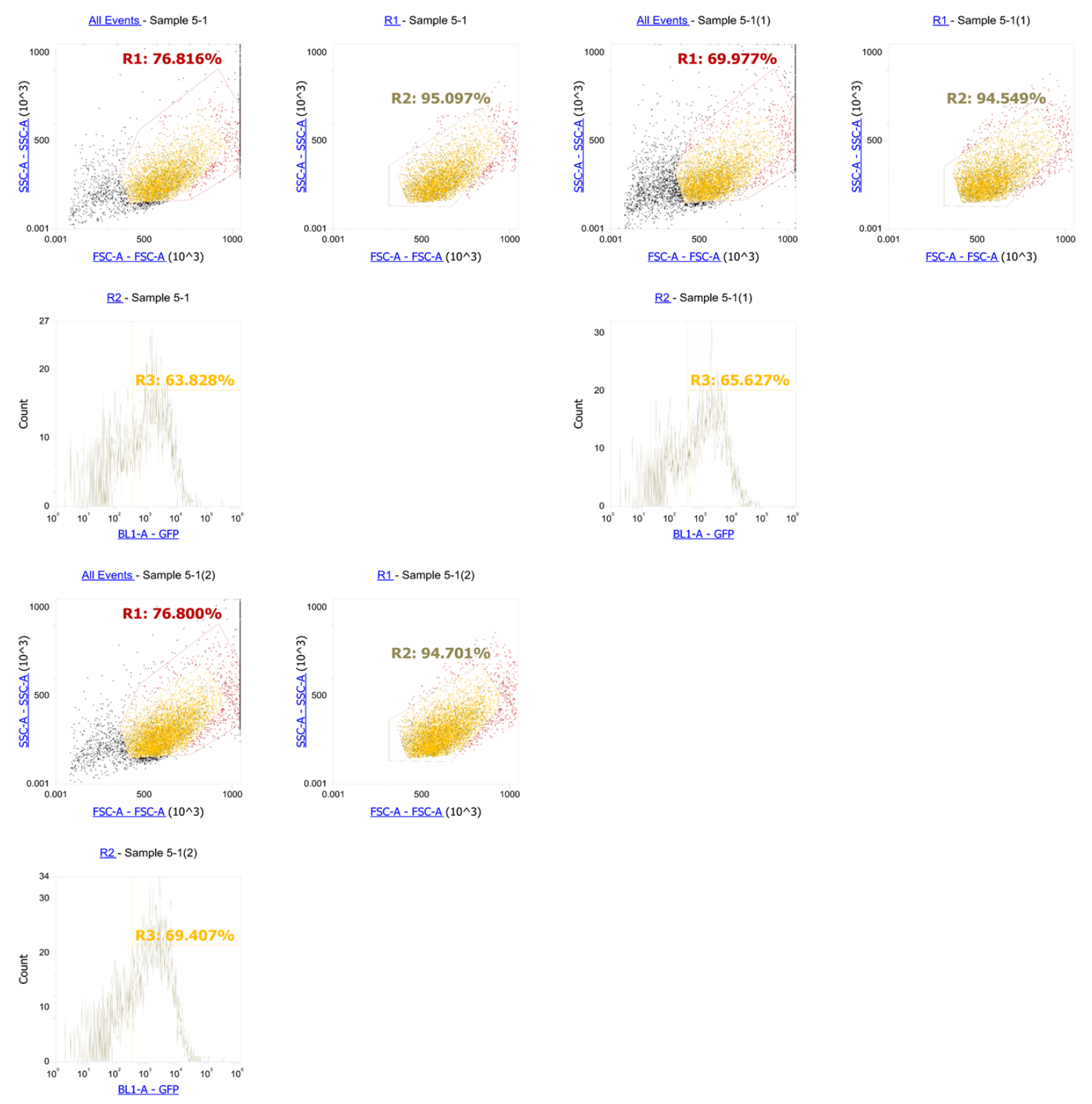

Figure S12: Histograms for Hela cells transfected with GFP-expressing mRNA with Lipofectamine $(0.2 \mu \mathrm{L} / \mathrm{mL})$ and PCS $(2 \mu \mathrm{g} / \mathrm{mL})$. 


\section{Hela PCS Cell Toxicity}

Hela cells were transfected by first adding PCS $(2 \mu \mathrm{g} / \mathrm{mL})$ to CleanCap® eGFP mRNA $(0.5 \mu \mathrm{g} / \mathrm{mL})$ (Trilink Biotechnologies, San Diego, CA), followed by incubation for 30 minutes at room temperature. Then, Lipofectamine 2000 was added at different amounts followed by an additional 30 -minute incubation. The resulting mixture was then added to Hela cells in a 96-well plate in OptiMEM media. The cells were incubated for 24 hours before eGFP expression was measured by flow cytometry. The toxicity of PCS alone was measured on Hela cells using a simple Resazurin assay. As seen in Figure S13, this showed a CC50\% of roughly $50 \mu \mathrm{g} / \mathrm{mL}$, which was significantly higher than the concentrations used for mRNA transfections, which was $2 \mu \mathrm{g} / \mathrm{mL}$.

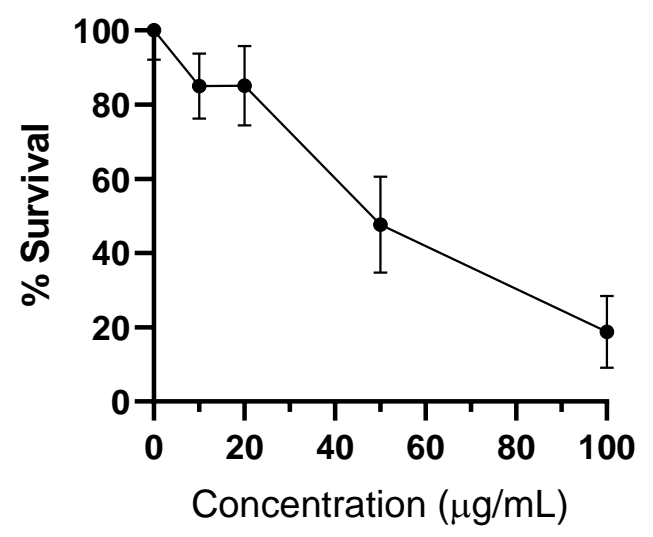

Figure S13: PCS shows toxicity on Hela cells with a CC50\% of roughly 50ug/mL. This is above the concentration used for transfection, which was $2 \mu \mathrm{g} / \mathrm{mL}$ for Hela cells. 


\section{Flow Cytometry Histograms - HUVECs}
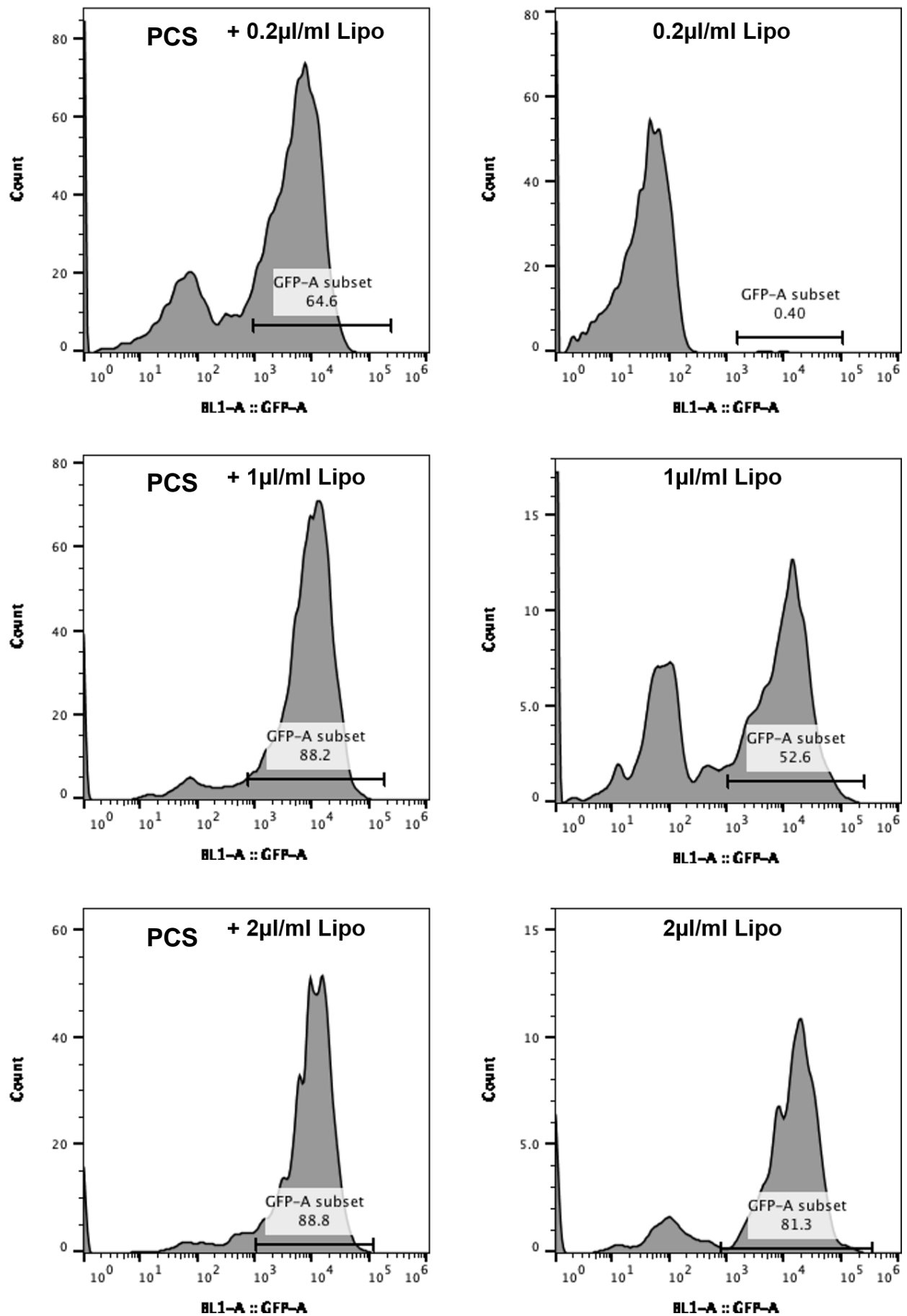

Figure S14: Representative flow cytometry histograms for transfection of HUVECs with PCS/Lipo and Lipofectamine 2000 alone at $0.2,1$, and $2 \mu \mathrm{L} / \mathrm{mL}$ of Lipofectamine. PCS concentrations are kept constant at $2 \mu \mathrm{g} / \mathrm{mL}$. The transfection was expressed as the percentage of positive cells/total cells. This also takes into consideration the toxicity that is caused by Lipofectamine 2000, and is a better measurement of the total efficiency of the system. 


\section{TCS Toxicity}

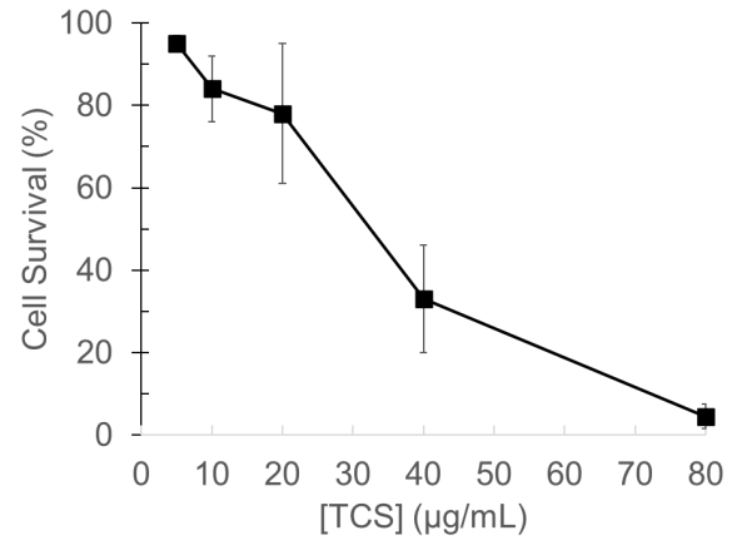

Figure S15: TCS toxicity to Hela cells. The lowest concentration that gave $<20 \%$ toxicity was at $10 \mu \mathrm{g} / \mathrm{mL}$ of TCS after a $24 \mathrm{hr}$ incubation and subsequent resazurin assay.

\section{3. siRNA delivery by Lipofectamine}

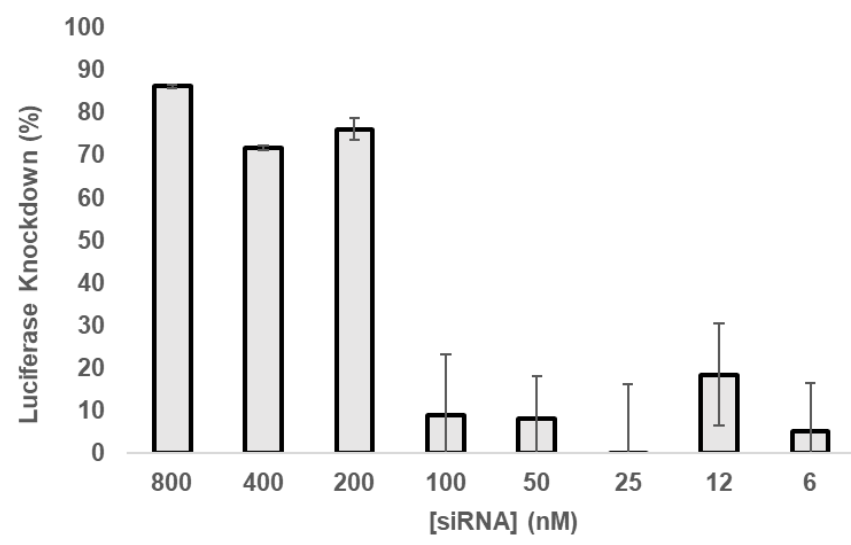

Figure S16: Lipofectamine needs 200nM of siRNA for efficient Luciferase knockdown at same conditions as TCS. In comparison, TCS efficiently delivered siRNA down to $25 \mathrm{nM}$ concentrations. 


\section{Synthesis and Characterization of $\mathrm{HO}-\mathrm{PEG}_{4}-\mathrm{N}_{3}$}

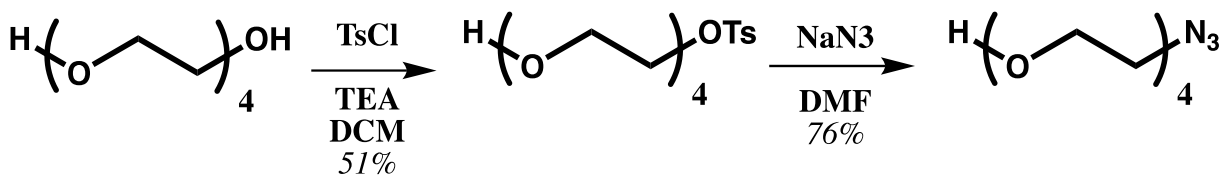

Scheme S1: Synthetic scheme of HO-PEG4-N3.

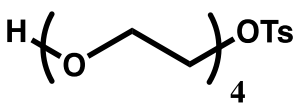

5

2-(2-(2-(2-hydroxyethoxy)ethoxy)ethoxy)ethyl 4-methylbenzenesulfonate (5): To a solution of tetraethylene glycol $(26.7 \mathrm{~mL}, 154 \mathrm{mmol}, 2 \mathrm{eq})$ in $\mathrm{DCM}(500 \mathrm{~mL})$ was added TsCl $(14.7 \mathrm{~g}, 77 \mathrm{mmol}, 1 \mathrm{eq})$ and TEA (41.8 mL, $300 \mathrm{mmol}, 3.9 \mathrm{eq})$. The mixture was stirred at room temperature for 22 hours. The reaction mixture was then washed with saturated ammonium chloride and extracted with additional DCM. The combined organic layers were dried and concentrated. The crude product was purified by flash chromatography (100\% DCM) to afford a colorless oil (13.58 g, $62.8 \mathrm{mmol}, 51 \%$ yield). ${ }^{1} \mathrm{H}$ NMR (600 MHz, Chloroform-d) $\delta 7.80(\mathrm{~d}, \mathrm{~J}=8.1 \mathrm{~Hz}, 2 \mathrm{H}), 7.34(\mathrm{~d}, \mathrm{~J}=8.0 \mathrm{~Hz}, 2 \mathrm{H}), 4.16(\mathrm{t}, \mathrm{J}=4.8 \mathrm{~Hz}, 2 \mathrm{H}), 3.86-$ 3.57 (m, 14H), 2.45 (s, 3H), 2.27 (b, 1H). ${ }^{13} \mathrm{C}$ NMR (151 MHz, Chloroform-d) $\delta 144.94,133.15,129.97$, 128.14, 72.58, 70.90, 70.82, 70.64, 70.50, 69.39, 68.87, 61.90, 21.80. HRMS (ESI+): Found: 371.1135m/z, Calc: $371.1135 \mathrm{~m} / \mathrm{z}$ for $\left[\mathrm{C}_{15} \mathrm{H}_{24} \mathrm{O}_{7} \mathrm{SNa}\right]^{+}$

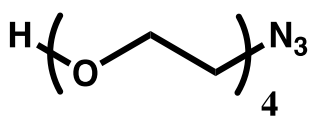

6

2-(2-(2-(2-azidoethoxy)ethoxy)ethoxy)ethan-1-ol (6): To a solution of 5 (994.5 mg, $2.85 \mathrm{mmol}, 1$ eq) in DMF (10 mL) was added sodium azide $(986 \mathrm{mg}, 15.17 \mathrm{mmol}, 5 \mathrm{eq})$. The mixture was set to reflux at $60^{\circ} \mathrm{C}$ for 5 hours, after which it was concentrated and resuspended in water. The mixture was extracted with DCM and washed with water and brine. The organic phase was dried with sodium sulfate, filtered, and concentrated. The resulting crude product was purified by flash chromatography (100\% EtOAc to 1:19 $\mathrm{MeOH}:$ EtOAc) to yield a colorless oil (477.7 mg, $2.18 \mathrm{mmol}, 76 \%$ yield). ${ }^{1} \mathrm{H}$ NMR (600 MHz, Chloroformd) $\delta 3.73(\mathrm{t}, \mathrm{J}=4.5 \mathrm{~Hz}, 2 \mathrm{H}), 3.70-3.66(\mathrm{~m}, 10 \mathrm{H}), 3.62(\mathrm{t}, \mathrm{J}=4.5 \mathrm{~Hz}, 2 \mathrm{H}), 3.40(\mathrm{t}, \mathrm{J}=5.1 \mathrm{~Hz}, 2 \mathrm{H}), 2.13$ (b, 1H). ${ }^{13} \mathrm{C}$ NMR (151 MHz, Chloroform-d) $\delta$ 72.60, 70.87, 70.84, 70.77, 70.53, 70.21, 61.92, 50.83. HRMS (ESI+): Found: $242.1110 \mathrm{~m} / \mathrm{z}$, Calc: $242.1111 \mathrm{~m} / \mathrm{z}$ for $\left[\mathrm{C}_{8} \mathrm{H}_{17} \mathrm{O}_{4} \mathrm{~N}_{3} \mathrm{Na}\right]^{+}$ 


\section{Synthesis of Ald-C8-PEG}

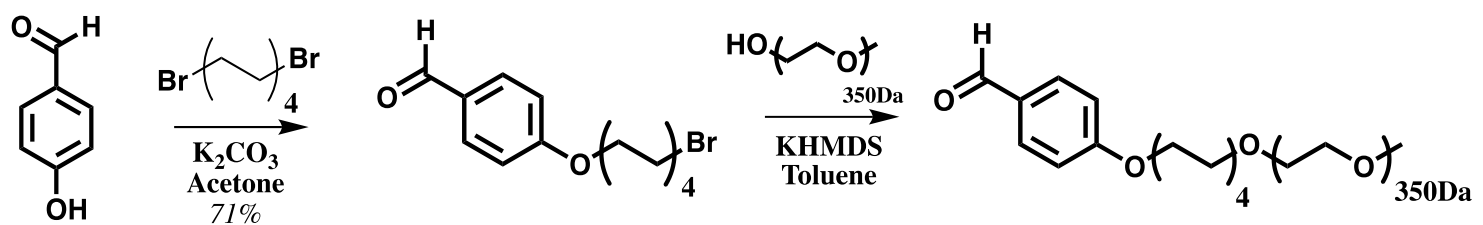

Scheme S2: Synthetic scheme for Ald-C8-PEG.

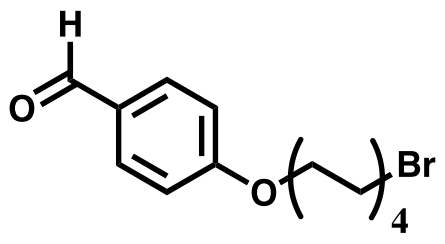

1

4-((8-bromooctyl)oxy)benzaldehyde (1): To a solution of 4-hydroxybenzaldehyde (2.4025 g, 19.7 $\mathrm{mmol}, 1 \mathrm{eq})$ in acetone $(100 \mathrm{~mL})$ was added 1,8-dibromooctane $(11 \mathrm{~mL}, 16 \mathrm{~g}, 59.4 \mathrm{mmol}, 3 \mathrm{eq})$ and anhydrous potassium carbonate $(5.4064 \mathrm{~g}, 39.1 \mathrm{mmol}, 2 \mathrm{eq})$. The mixture was set to reflux at $70^{\circ} \mathrm{C}$ for 13.5 hours, after which it was concentrated and resuspended in DCM $(100 \mathrm{~mL})$. The organic phase was washed with brine $(100 \mathrm{~mL})$, dried with sodium sulfate, filtered and concentrated. The resulting crude was purified by flash chromatography (100\% hexanes to 1:9 EtOAc:hexanes) to yield a colorless solid (4.3620 g, 13.93 mmol, $71 \%$ yield). ${ }^{1} \mathrm{H}$ NMR (400 MHz, Chloroform-d) $\delta 9.87(\mathrm{~s}, 1 \mathrm{H}), 7.82(\mathrm{~d}, \mathrm{~J}=8.8 \mathrm{~Hz}, 2 \mathrm{H}), 6.98(\mathrm{~d}, \mathrm{~J}$ $=8.8 \mathrm{~Hz}, 2 \mathrm{H}), 4.03(\mathrm{t}, \mathrm{J}=6.5 \mathrm{~Hz}, 2 \mathrm{H}), 3.41(\mathrm{t}, \mathrm{J}=6.8 \mathrm{~Hz}, 2 \mathrm{H}), 2.04-1.74(\mathrm{~m}, 4 \mathrm{H}), 1.56-1.30(\mathrm{~m}, 8 \mathrm{H})$. ${ }^{13} \mathrm{C}$ NMR (101 MHz, Chloroform-d) $\delta 190.96,164.34,132.13,129.88,114.86,68.46,34.12,32.88,29.27$, 29.14, 28.79, 28.20, 26.01. HRMS (EI+): Found: $312.0722 \mathrm{~m} / \mathrm{z}$, Calc: $312.0725 \mathrm{~m} / \mathrm{z}$ for $\left[\mathrm{C}_{15} \mathrm{H}_{21} \mathrm{O}_{2} \mathrm{Br}\right]^{+}$

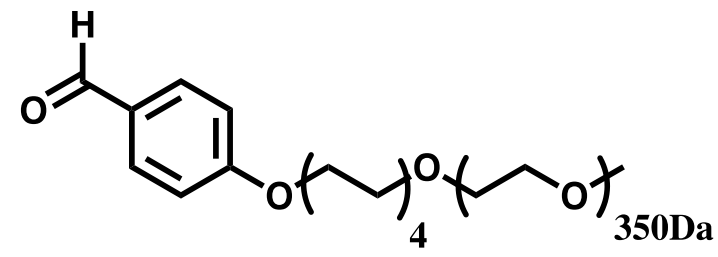

Ald-C8-PEG

4-((8-(PEG $350 \mathrm{Da})$ octyl))benzaldehyde (Ald-C8-PEG): To a mixture of $\mathrm{HO}-\mathrm{PEG}_{350 \mathrm{Da}-\mathrm{OMe}}(2.124 \mathrm{~g}$, $6.07 \mathrm{mmol}, 0.95 \mathrm{eq})$ in toluene $(16 \mathrm{~mL})$ was added $4 \AA$ molecular sieves. The mix ture was cooled to $0^{\circ} \mathrm{C}$ under a nitrogen flow, and KHMDS (15\% in toluene, $9.31 \mathrm{~mL}, 1.21 \mathrm{~g}, 6.07 \mathrm{mmol}, 0.95 \mathrm{eq}$ ) was added dropwise. After stirring for 10 minutes, a mixture of aldehyde $(2.003 \mathrm{~g}, 6.36 \mathrm{mmol}, 1 \mathrm{eq})$ in toluene $(12 \mathrm{~mL})$ was added dropwise to the mixture. The reaction was then allowed to heat to room temperature overnight while stirring. The reaction was then quenched with sat. $\mathrm{NH}_{4} \mathrm{Cl}$, and extracted into DCM $(3 \times 100 \mathrm{~mL})$. The organic phases were dried with brine and $\mathrm{Na}_{2} \mathrm{SO}_{4}$, before purifying by silica column chromatography (DCM:MeOH; 1:0 
to $95: 5)$ to yield an orange-tinted oil (205.6mg, $0.35 \mathrm{mmol}, 6 \%$ yield). ${ }^{1} \mathrm{H}$ NMR (400 MHz, Chloroform- $d$ ) $\delta 9.88(\mathrm{~s}, 1 \mathrm{H}), 7.82(\mathrm{~d}, J=8.8 \mathrm{~Hz}, 2 \mathrm{H}), 6.98(\mathrm{~d}, J=8.7 \mathrm{~Hz}, 2 \mathrm{H}), 4.03(\mathrm{t}, J=6.5 \mathrm{~Hz}, 2 \mathrm{H}), 3.67-3.62(\mathrm{~m}$, $31 \mathrm{H}), 3.59-3.56(\mathrm{~m}, 2 \mathrm{H}), 3.56-3.53(\mathrm{~m}, 2 \mathrm{H}), 3.45(\mathrm{t}, J=6.8 \mathrm{~Hz}, 2 \mathrm{H}), 3.38(\mathrm{~s}, 3 \mathrm{H}), 1.84-1.76(\mathrm{~m}, 2 \mathrm{H})$, $1.63-1.54(\mathrm{~m}, 2 \mathrm{H}), 1.50-1.41(\mathrm{~m}, 2 \mathrm{H}), 1.38-1.30(\mathrm{~m}, 6 \mathrm{H}) .{ }^{13} \mathrm{C} \mathrm{NMR}\left(101 \mathrm{MHz}, \mathrm{CDCl}_{3}\right) \delta 190.98,164.40$, $132.14,114.89,72.09,71.62,70.73,70.22,68.53,59.19,29.75,29.52,29.41,29.18,26.17,26.05$. HRMS (ESI+): Found: $639.3711 \mathrm{~m} / \mathrm{z}$, Calc: $639.3715 \mathrm{~m} / \mathrm{z}$ for $\left[\mathrm{C}_{32} \mathrm{H}_{56} \mathrm{O}_{11} \mathrm{Na}\right]^{+}$

\section{Synthesis of CS12-DITFAA}

N3-PEG4-NHCOCF3 (7) was synthesized as previously reported ${ }^{15}$.

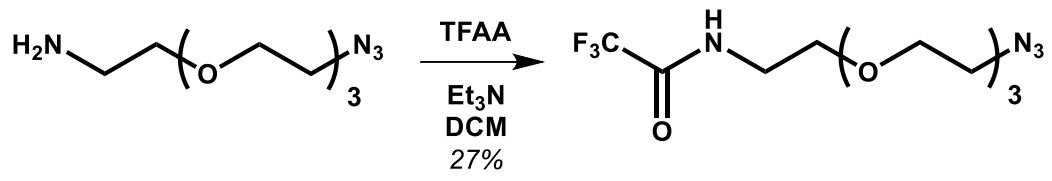

Scheme S3: Synthetic scheme for the synthesis of $\mathrm{N}_{3}-\mathrm{PEG} 4-\mathrm{NHCOCF}$.

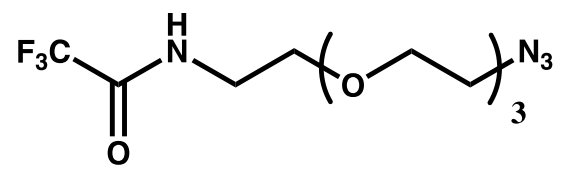

7

N-(2-(2-(2-(2-azidoethoxy)ethoxy)ethoxy)ethyl)-2,2,2-trifluoroacetamide (7): A mixture of 2-(2(2-(2-azidoethoxy)ethoxy)ethoxy)ethan-1-amine $(2 \mathrm{~g}, 9.2 \mathrm{mmol}, 1 \mathrm{eq})$ and TEA $(1.55 \mathrm{~mL}, 1.13 \mathrm{~g}, 11.2 \mathrm{mmol}$, $1.2 \mathrm{eq})$ in DCM $(20 \mathrm{~mL})$ was cooled to $0^{\circ} \mathrm{C}$ under a flow of nitrogen. Then, TFAA $(1.55 \mathrm{~mL}, 2.3 \mathrm{~g}, 11 \mathrm{mmol}$, 1.2eq) was added dropwise, and the reaction was left to slowly cool to room temperature overnight. DCM $(150 \mathrm{~mL})$ and $\mathrm{DI} \mathrm{H}_{2} \mathrm{O}(100 \mathrm{~mL})$ were added, and the organic phase was collected. The organic phase was added to sat. $\mathrm{NaHCO}_{3}(100 \mathrm{~mL})$ and the organic phase was collected, and dried with $\mathrm{Na}_{2} \mathrm{SO}_{4}$ and concentrated. The crude product was purified by silica chromatography (MeOH:DCM from 2:98 to 5:95) to yield 7 as a colorless oil $\left(784.8 \mathrm{mg}, 2.5 \mathrm{mmol}, 27 \%\right.$ yield). The ${ }^{1} \mathrm{H}$ and ${ }^{13} \mathrm{C}$ NMR corresponded with that previously reported. ${ }^{1} \mathrm{H}$ NMR $(400 \mathrm{MHz}$, Chloroform- $d$ ) $\delta 7.11(\mathrm{~s}, 1 \mathrm{H}), 3.73-3.58(\mathrm{~m}, 12 \mathrm{H}), 3.58-3.49$ $(\mathrm{m}, 2 \mathrm{H}), 3.42-3.33(\mathrm{~m}, 2 \mathrm{H}) .13 \mathrm{C}$ NMR $(226 \mathrm{MHz}, \mathrm{CDCl} 3) \delta 157.36(\mathrm{~d}, \mathrm{~J}=37.0 \mathrm{~Hz}), 116.05(\mathrm{~d}, \mathrm{~J}=287.9$ $\mathrm{Hz}$ ), 70.84, 70.82, 70.72, 70.48, 70.21, 68.84, 50.81, 39.86. HRMS (ESI+): Found $337.1089 \mathrm{~m} / \mathrm{z}$, Calc $337.1094 \mathrm{~m} / \mathrm{z}$ for $\left[\mathrm{C}_{10} \mathrm{H}_{17} \mathrm{O}_{4} \mathrm{~N}_{4} \mathrm{~F}_{3} \mathrm{Na}\right]^{+}$. 


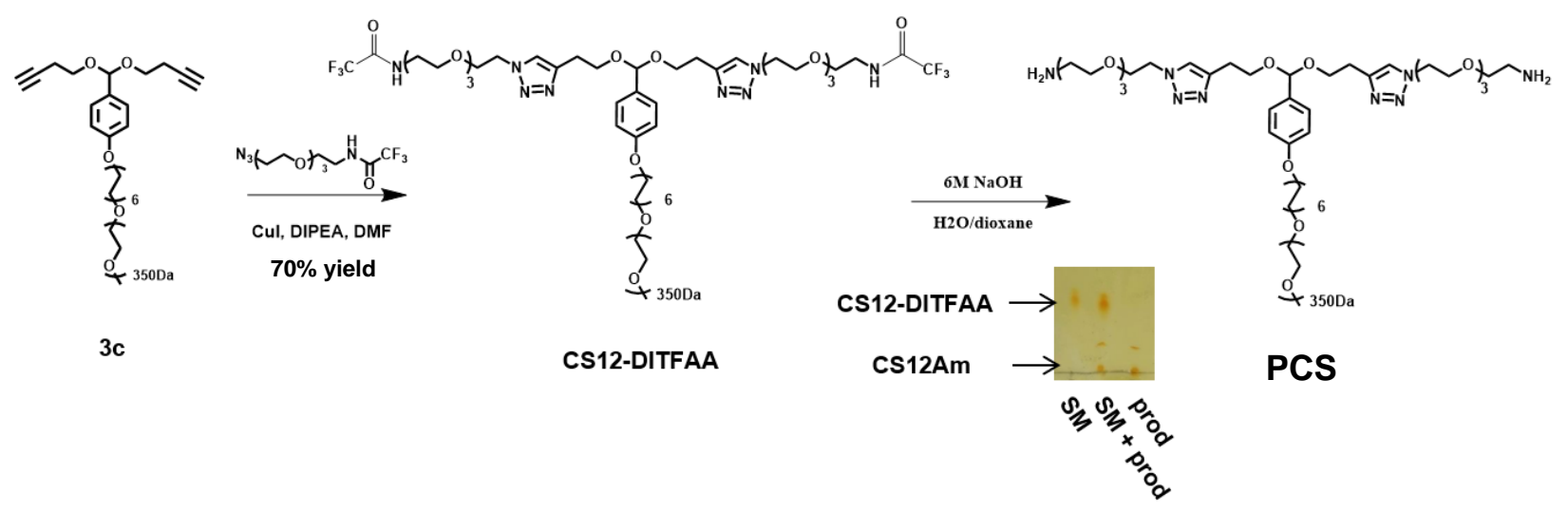

Scheme S4: Synthetic scheme for PCS..

CS12-DITFAA: To a solution of $4 \mathbf{c}(301.4 \mathrm{mg}, 0.4 \mathrm{mmol}, 1 \mathrm{eq})$ in DMF (2mL) and DIPEA $(209 \mu \mathrm{L}$, $155 \mathrm{mg}, 1.2 \mathrm{mmol}$, 3eq) was added 7 (499.8mg, 1.6mmol, 4eq) and CuI (15mg, 0.08mmol, 0.2eq). Nitrogen gas was bubbled through the reaction mixture for 30 minutes, and the reaction was set to stir at room temperature for 48 hours before DMF was removed throu gh co-evaporation with toluene $(2 \times 100 \mathrm{~mL})$. The crude product was purified by silica chromatography (MeOH:DCM:TEA from 2:98:0.2 to 5:95:0.2) to yield CS12-DITFAA as a clear oil (391mg, $0.28 \mathrm{mmol}, 70 \%$ yield). ${ }^{1} \mathrm{H}$ NMR (400 MHz, MeOD) $\delta 7.80$ (s, 2H), $7.26(\mathrm{~d}, \mathrm{~J}=8.6 \mathrm{~Hz}, 2 \mathrm{H}), 6.86(\mathrm{~d}, \mathrm{~J}=8.7 \mathrm{~Hz}, 2 \mathrm{H}), 5.49(\mathrm{~s}, 1 \mathrm{H}), 4.53(\mathrm{t}, \mathrm{J}=5.0 \mathrm{~Hz}, 4 \mathrm{H}), 3.96(\mathrm{t}, \mathrm{J}=6.5 \mathrm{~Hz}$, 2H), $3.85(\mathrm{t}, \mathrm{J}=5.1 \mathrm{~Hz}, 4 \mathrm{H}), 3.77-3.42(\mathrm{~m}, 57 \mathrm{H}), 3.35(\mathrm{~s}, 3 \mathrm{H}), 2.94(\mathrm{t}, \mathrm{J}=6.5 \mathrm{~Hz}, 3 \mathrm{H}), 1.75(\mathrm{q}, \mathrm{J}=7.0$ $\mathrm{Hz}, 2 \mathrm{H}), 1.56$ (q, J = 6.8 Hz, 2H), 1.47 (s, 2H), 1.32 (s, 14H). ${ }^{13} \mathrm{C}$ NMR (226 MHz, MeOD) $\delta 160.75$, 146.17, 131.86, 129.01, 124.81, 115.10, 103.05, 73.68, 72.99, 72.38, 71.65, 71.59, 71.57, 71.53, 71.51, 71.42, 71.38, 71.31, 71.19, 71.13, 70.44, 69.73, 69.03, 65.55, 59.10, 51.77, 51.31, 40.76, 40.72, 30.74, 30.70, 30.58, 30.52, 30.42, 27.23, 10.96. HRMS (ESI+): Found: $1357.6988 \mathrm{~m} / \mathrm{z} \mathrm{Calc:} 1357.6952 \mathrm{~m} / \mathrm{z}$ for $\left[\mathrm{C}_{60} \mathrm{H}_{100} \mathrm{O}_{18} \mathrm{~N}_{8} \mathrm{~F}_{6} \mathrm{Na}\right]^{+}$.

\section{TO-PEG4-N3 Synthesis}

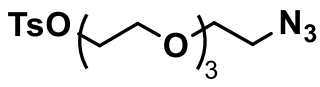

8

2-(2-(2-(2-azidoethoxy)ethoxy)ethoxy)ethyl 4-methylbenzenesulfonate (8): Compound 8 was synthesized according to previously reported procedures. Briefly, to a solution of $6(2.55 \mathrm{~g}, 11.6 \mathrm{mmol}, 1 \mathrm{eq})$ in DCM $(100 \mathrm{~mL})$ was added $\mathrm{TsCl}(5.6249 \mathrm{~g}, 29.5 \mathrm{mmol}, 2.5 \mathrm{eq})$ and TEA (4.1mL, 2.97g, 29.4mmol, 2.5eq). The reaction was allowed to stir at room temperature overnight. The solution was then added saturated $\mathrm{NH} 4 \mathrm{Cl}$ $(50 \mathrm{~mL})$, and the organic phase was collected. The organic phase was washed with brine $(50 \mathrm{~mL})$, and the organic phase was further dried with $\mathrm{Na} 2 \mathrm{SO} 4$ and concentrated by rotary evaporation. The resulting crude was purified by silica flash chromatography to yield $\mathbf{8}$ as a colorless oil (3.0558g, 8.2mmol, $71 \%$ yield). The NMR and HRMS data matched with that previously reported. 


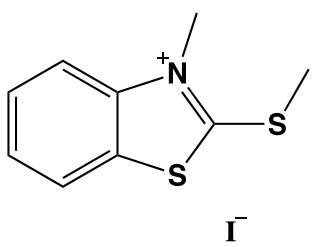

9

3-methyl-2-(methylthio)benzo[d]thiazol-3-ium iodide (9): To a round bottom flask containing 2(methylthio)benzo[d]thiazole $(0.5 \mathrm{~g}, 2.76 \mathrm{mmol}, 1 \mathrm{eq})$ was added iodomethane $(515 \mu \mathrm{L}, 1.17 \mathrm{~g}, 8.27 \mathrm{mmol}$, 3eq), and the reaction was allowed to stir at $100^{\circ} \mathrm{C}$ overnight. The resulting mixture was filtered, and the solid was washed with cold diethyl ether. The residue was isolated to give $\mathbf{9}$ as an off-white fine powder (256.1 mg, 0.79mmol, 29\% yield). ${ }^{1} \mathrm{H}$ NMR (400 MHz, DMSO- $\left.d_{6}\right) \delta 8.39(\mathrm{~d}, J=8.1 \mathrm{~Hz}, 1 \mathrm{H}), 8.20(\mathrm{~d}, J=$ $8.4 \mathrm{~Hz}, 1 \mathrm{H}), 7.92-7.79(\mathrm{~m}, 1 \mathrm{H}), 7.73(\mathrm{t}, J=7.7 \mathrm{~Hz}, 1 \mathrm{H}), 4.11(\mathrm{~s}, 3 \mathrm{H}), 3.12(\mathrm{~s}, 3 \mathrm{H}) .{ }^{13} \mathrm{C} \mathrm{NMR}(101 \mathrm{MHz}$, DMSO) $\delta 181.25,142.54,129.17,128.26,127.01,124.00,115.73,36.51,18.14$. HRMS (ESI+): Found: $196.0249 \mathrm{~m} / \mathrm{z}$ Calc: $196.0249 \mathrm{~m} / \mathrm{z}$ for $\left[\mathrm{C}_{9} \mathrm{H}_{10} \mathrm{NS}_{2}\right]^{+}$.

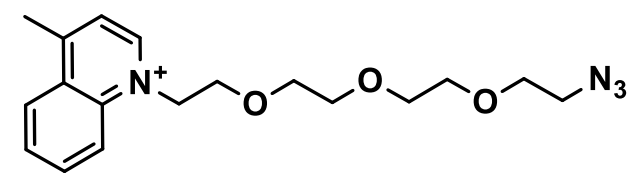

10

1-(2-(2-(2-(2-azidoethoxy)ethoxy)ethoxy)ethyl)-4-methylquinolin-1-ium iodide (10): To a solution of lepidine $(2.6 \mathrm{~mL}, 2.82 \mathrm{~g}, 19.7 \mathrm{mmol}, 5 \mathrm{eq})$ was added $\mathbf{8}(1.5009 \mathrm{~g}, 4 \mathrm{mmol}, 1 \mathrm{eq})$ in ethyl acetate $(4 \mathrm{~mL})$, and the reaction was allowed to stir at $50^{\circ} \mathrm{C}$ overnight. The mixture was then concentrated, and directly purified by neutral alumina flash chromatography $(2-4 \% \mathrm{MeOH}$ in DCM) to yield $\mathbf{1 0}$ as a blue/purple oil (727mg, 2.1mmol, 53\% yield). ${ }^{1} \mathrm{H}$ NMR $(900 \mathrm{MHz}, \mathrm{MeOD}) \delta 9.20(\mathrm{~d}, J=6.0 \mathrm{~Hz}, 1 \mathrm{H}), 8.58(\mathrm{dd}, J=8.5,1.3 \mathrm{~Hz}$, $2 \mathrm{H}), 8.26$ (ddd, $J=8.6,6.9,1.4 \mathrm{~Hz}, 1 \mathrm{H}), 8.11-8.03(\mathrm{~m}, 1 \mathrm{H}), 7.98(\mathrm{~d}, J=6.0 \mathrm{~Hz}, 1 \mathrm{H}), 5.24(\mathrm{t}, J=4.9 \mathrm{~Hz}$, 2H), $4.11-4.03(\mathrm{~m}, 2 \mathrm{H}), 3.63-3.58(\mathrm{~m}, 4 \mathrm{H}), 3.55-3.50(\mathrm{~m}, 4 \mathrm{H}), 3.50-3.48(\mathrm{~m}, 2 \mathrm{H}), 3.34(\mathrm{t}, J=4.9$ $\mathrm{Hz}, 2 \mathrm{H}), 3.10-3.06$ (m, 3H). ${ }^{13} \mathrm{C}$ NMR $(226 \mathrm{MHz}, \mathrm{MeOD}) \delta 161.06,150.29,138.92,136.50,130.98$, $130.93,128.28,123.43,120.26,71.73,71.56,71.46,71.02,69.20,58.39,54.81,51.75,20.30$. HRMS (ESI+): Found: $345.1919 \mathrm{~m} / \mathrm{z}$ Calc: $345.1921 \mathrm{~m} / \mathrm{z}$ for $\left[\mathrm{C}_{18} \mathrm{H}_{25} \mathrm{~N}_{4} \mathrm{O}_{3}\right]^{+}$. 


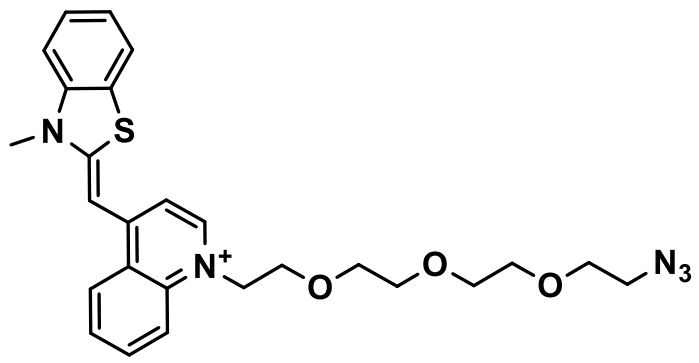

\section{TO-PEG 4 - $\mathbf{N}_{3}$}

(Z)-1-(2-(2-(2-(2-azidoethoxy)ethoxy)ethoxy)ethyl)-4-((3-methylbenzo[d]thiazol-2(3H)ylidene)methyl)quinolin-1-ium iodide (TO-PEG4-N3): To a solution of $\mathbf{9}(99.8 \mathrm{mg}, 0.31 \mathrm{mmol}, 1.07 \mathrm{eq})$ and $\mathbf{1 0}(99.6 \mathrm{mg}, 0.29 \mathrm{mmol}, 1 \mathrm{eq})$ in $\mathrm{EtOH}(4 \mathrm{~mL})$ in a nitrogen-purged pressure tube was added TEA $(120 \mu \mathrm{L}$,$) .$ The reaction was allowed to stir at $60^{\circ} \mathrm{C}$ for two hours, and the reaction was then concentrated and purified directly by neutral alumina flash chromatography $(0-2 \% \mathrm{MeOH}$ in DCM) to yield TO-PEG4-N3 as a red $\operatorname{tar}\left(89.6 \mathrm{mg}, 0.18 \mathrm{mmol}, 62 \%\right.$ yield). ${ }^{1} \mathrm{H}$ NMR $(900 \mathrm{MHz}, \mathrm{MeOD}) \delta 8.68(\mathrm{t}, J=8.0 \mathrm{~Hz}, 1 \mathrm{H}), 8.43-8.38(\mathrm{~m}$, $1 \mathrm{H}), 8.13-8.07(\mathrm{~m}, 1 \mathrm{H}), 7.99-7.93(\mathrm{~m}, 1 \mathrm{H}), 7.90(\mathrm{t}, J=7.8 \mathrm{~Hz}, 1 \mathrm{H}), 7.79-7.73(\mathrm{~m}, 1 \mathrm{H}), 7.66(\mathrm{dd}, J=$ 14.8, 8.2 Hz, 1H), $7.64-7.57(\mathrm{~m}, 1 \mathrm{H}), 7.50-7.44(\mathrm{~m}, 1 \mathrm{H}), 7.44-7.39(\mathrm{~m}, 1 \mathrm{H}), 6.95-6.89(\mathrm{~m}, 1 \mathrm{H}), 4.81$ $-4.75(\mathrm{~m}, 2 \mathrm{H}), 4.03-3.99(\mathrm{~m}, 3 \mathrm{H}), 3.97(\mathrm{t}, J=5.1 \mathrm{~Hz}, 2 \mathrm{H}), 3.64-3.59(\mathrm{~m}, 2 \mathrm{H}), 3.58-3.54(\mathrm{~m}, 4 \mathrm{H})$, $3.52-3.48(\mathrm{~m}, 4 \mathrm{H}), 3.28(\mathrm{t}, J=4.9 \mathrm{~Hz}, 2 \mathrm{H}) .{ }^{13} \mathrm{C}$ NMR $(226 \mathrm{MHz}, \mathrm{MeOD}) \delta 159.23,148.17,143.21$, 139.03, 136.03, 131.39, 126.54, 125.13, 123.70, 123.21, 122.95, 122.74, 120.73, 116.03, 110.76, 106.33, 86.26, 68.89, 68.68, 68.62, 68.53, 68.10, 66.45, 52.66, 48.75, 31.17. HRMS (ESI+): Found: 492.2058m/z Calc: $492.2064 \mathrm{~m} / \mathrm{z}$ for $\left[\mathrm{C}_{26} \mathrm{H}_{30} \mathrm{~N}_{5} \mathrm{O}_{3} \mathrm{~S}\right]^{+}$. 


\section{Mass Spectrometry Data}

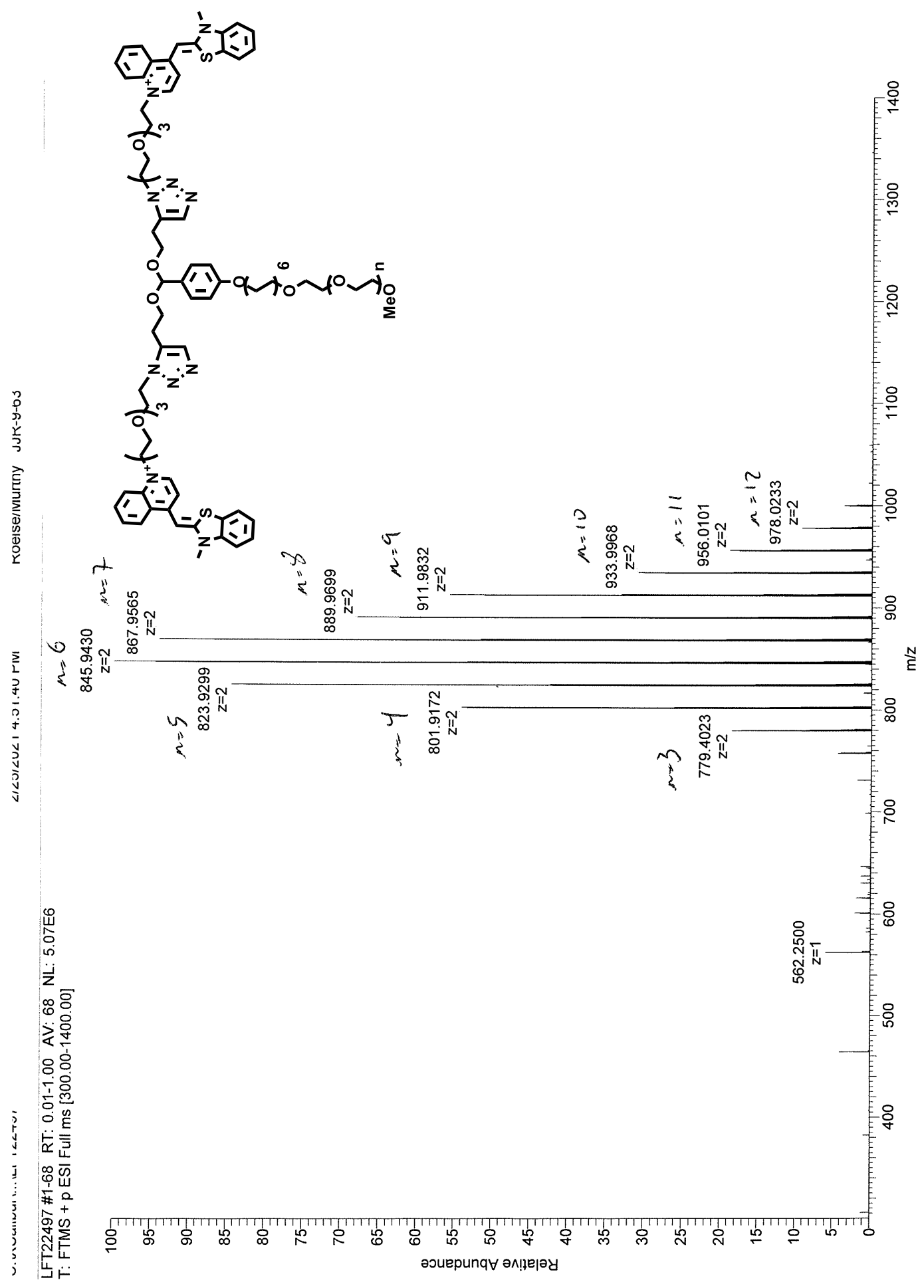




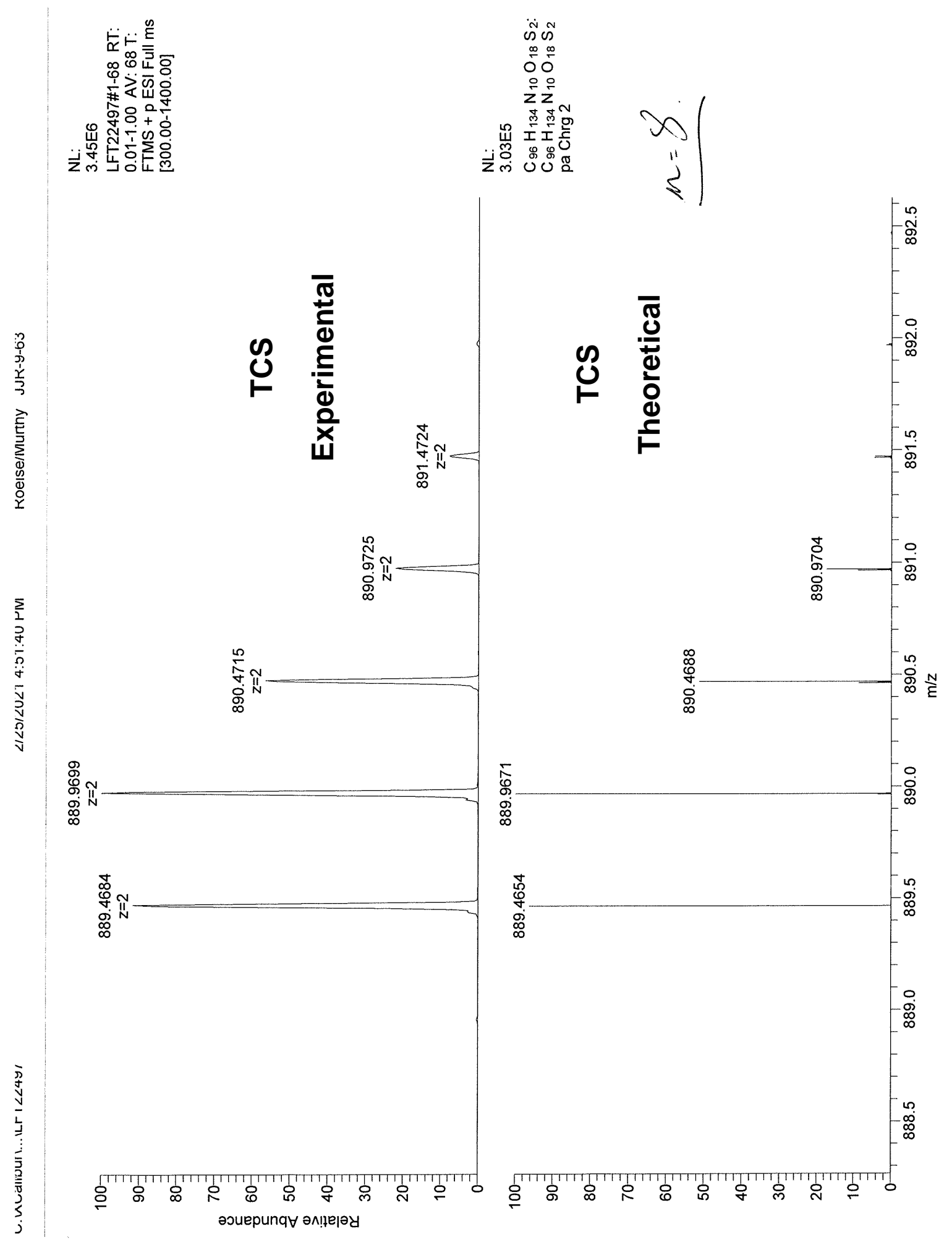




\section{NMR Spectra}

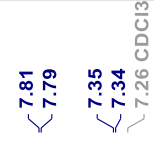

|

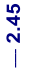
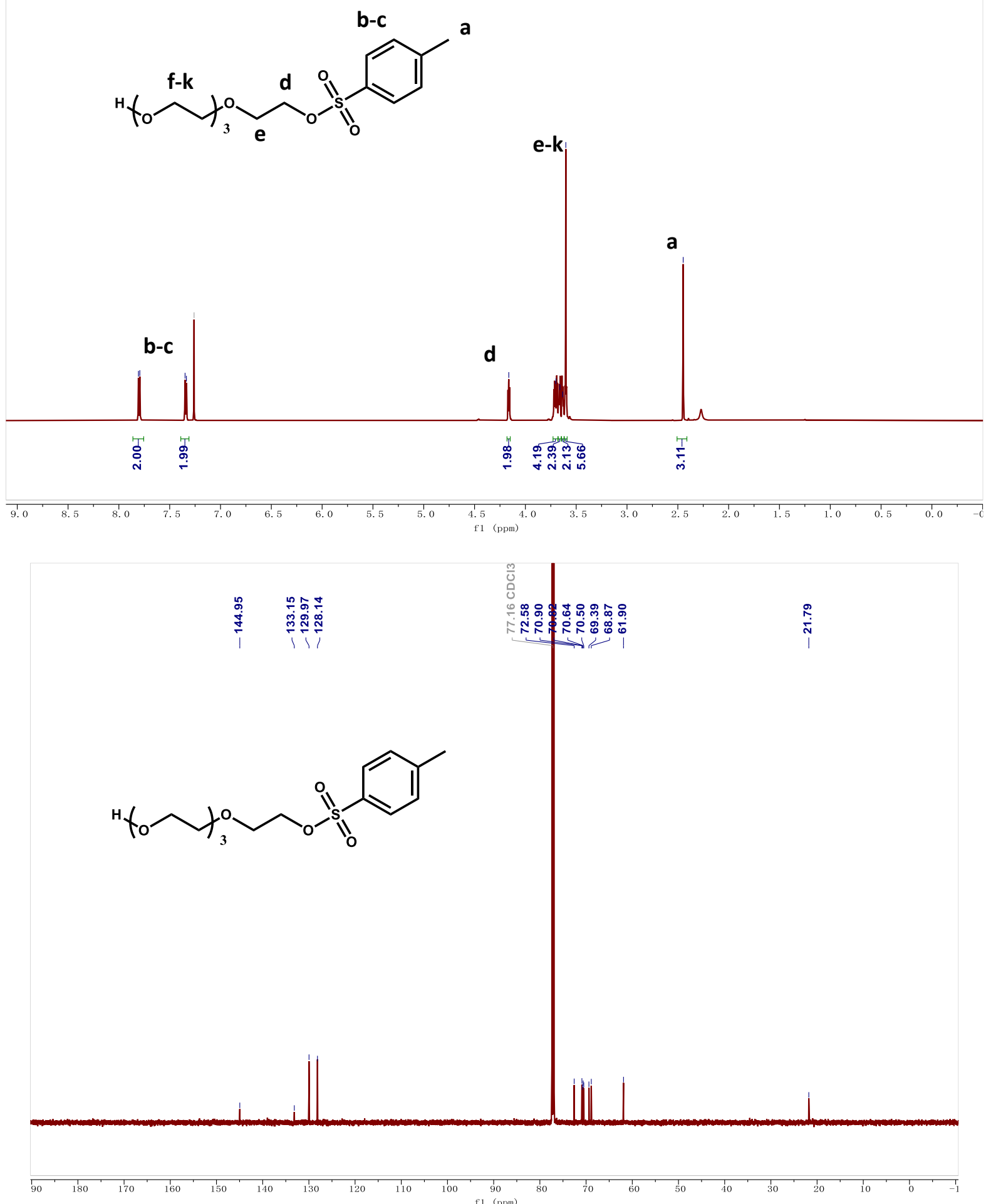

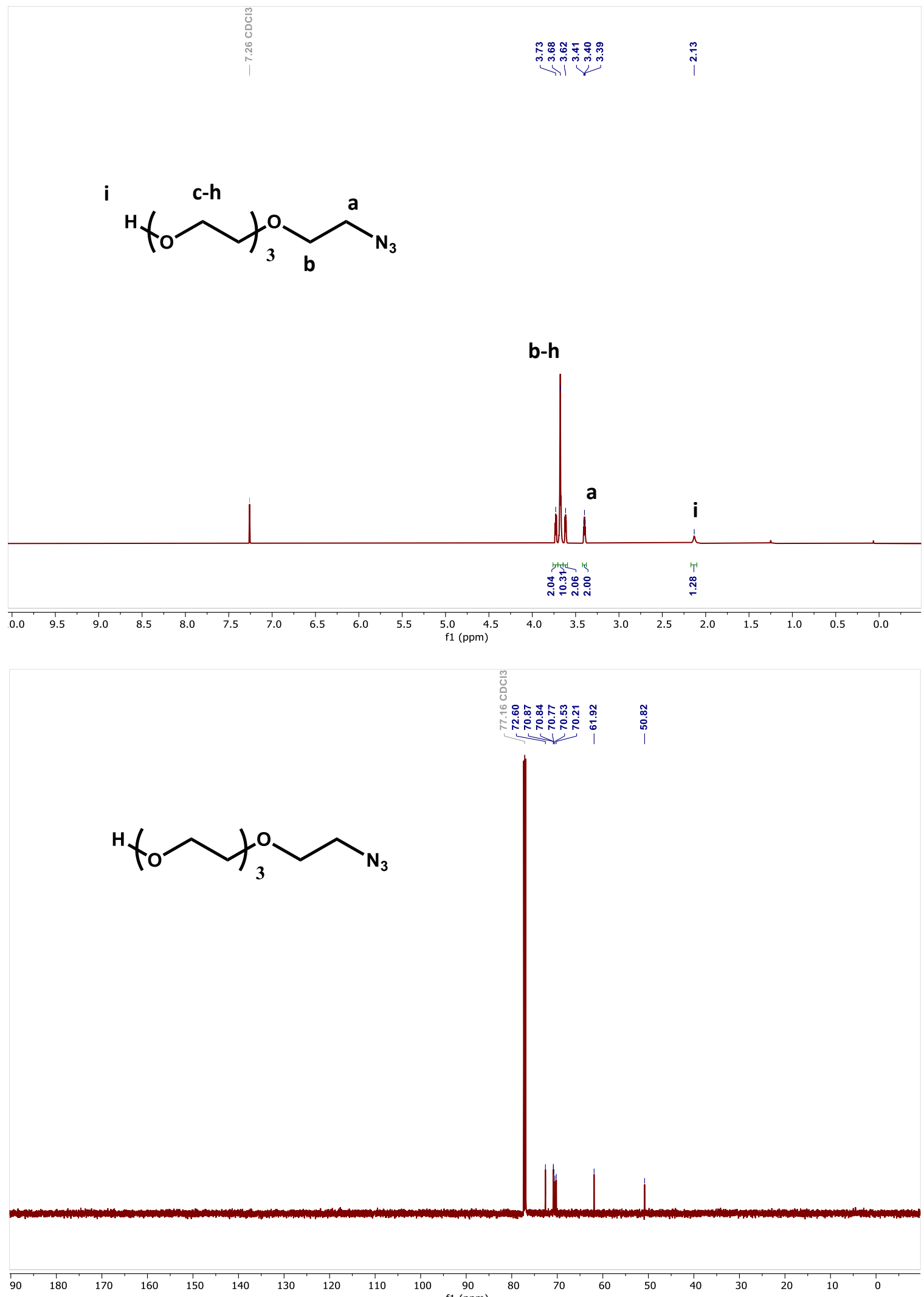

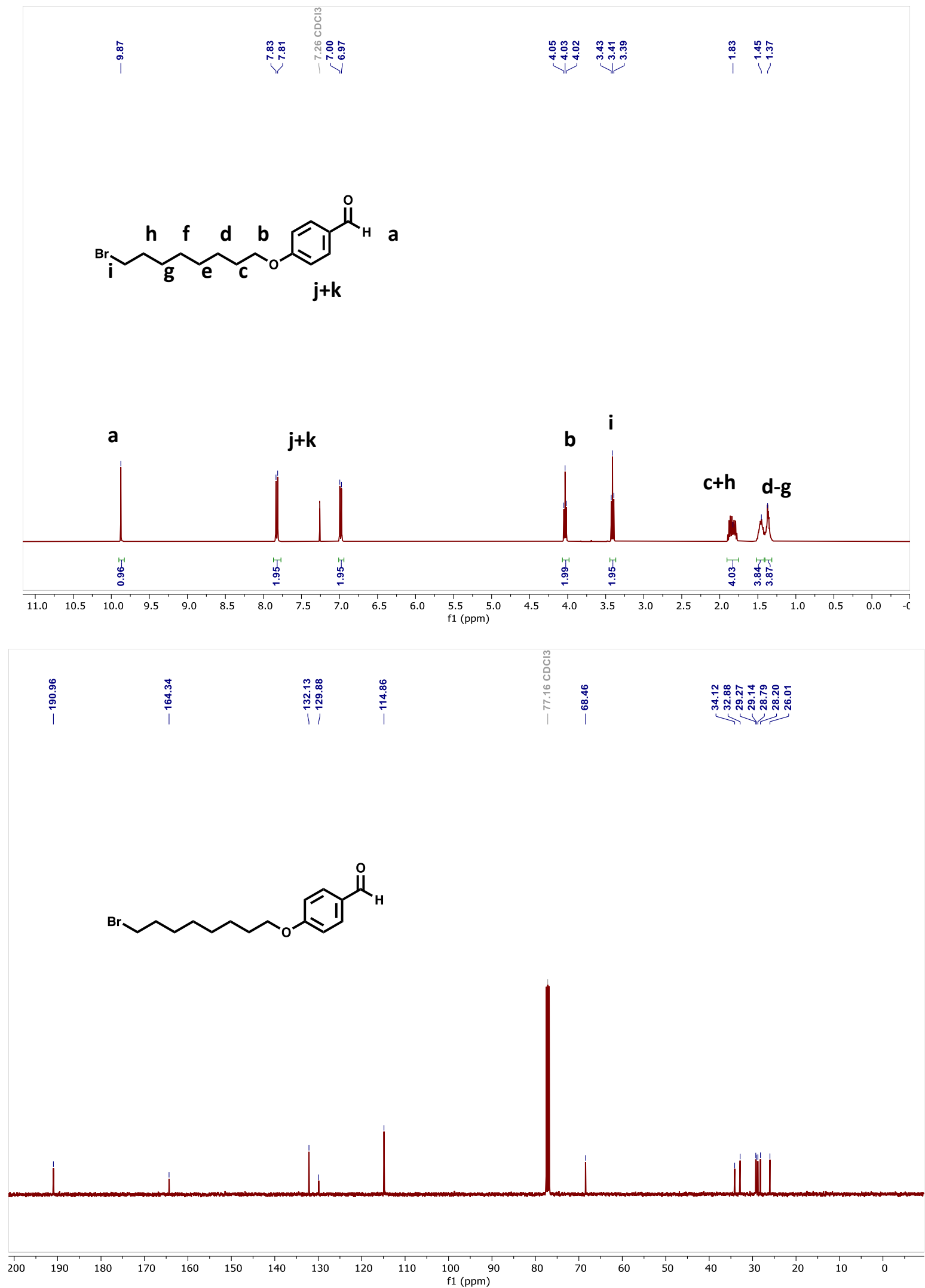

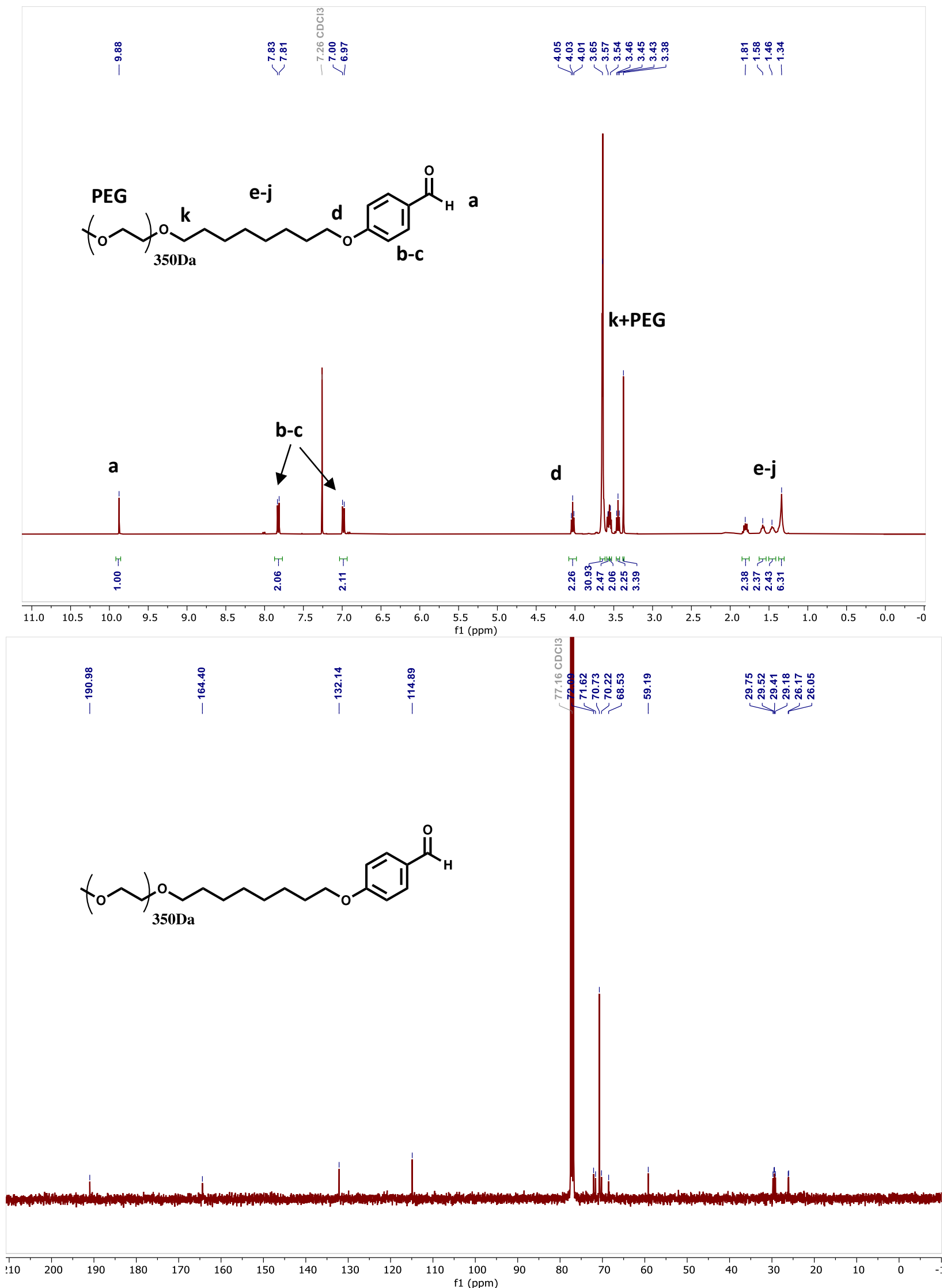

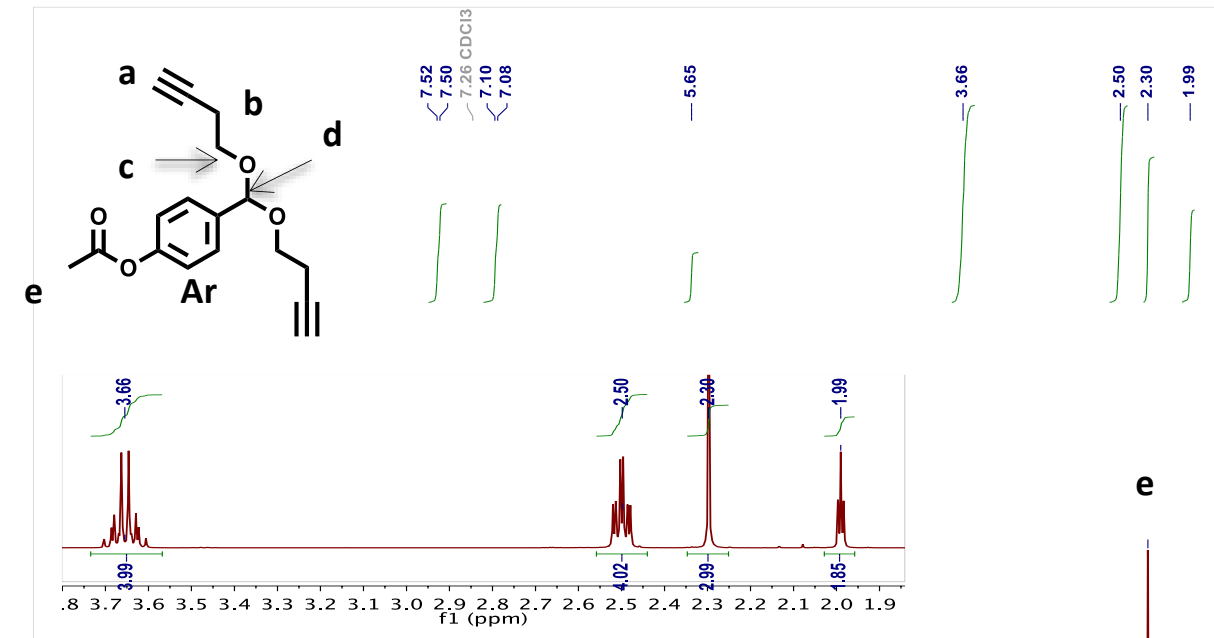

e
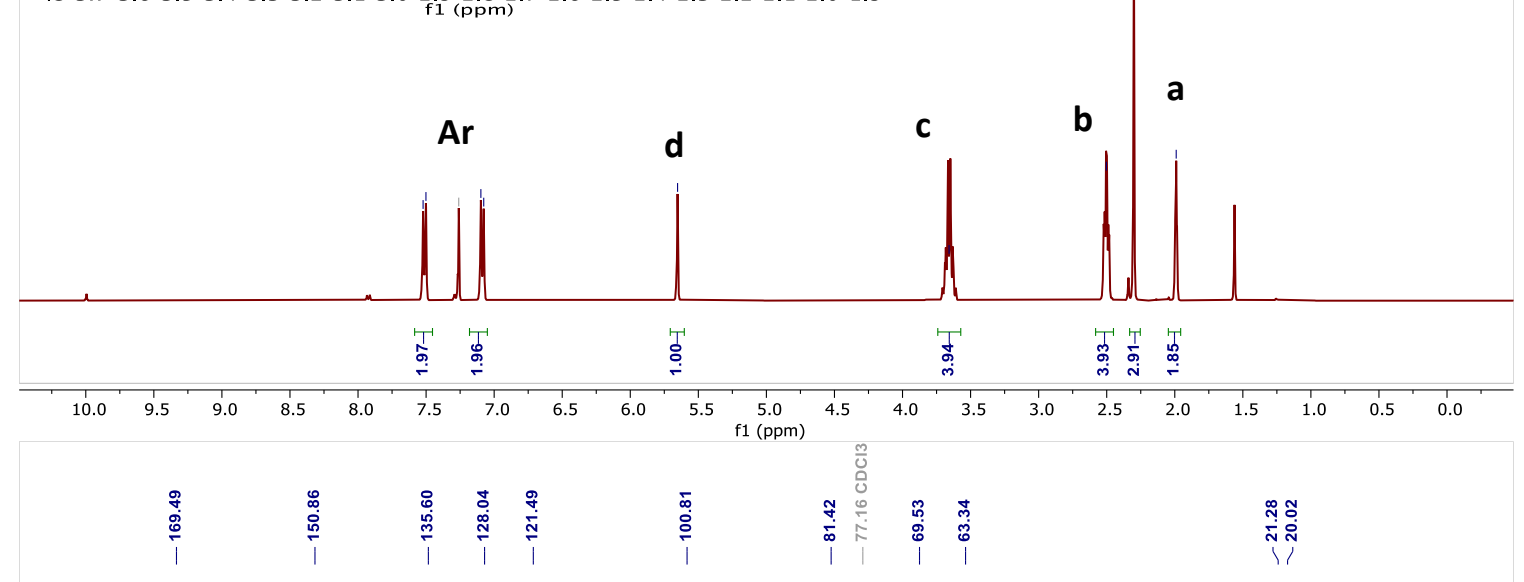<smiles>C#CCCOC(OCCC#C)c1ccc(OC(C)=O)cc1</smiles>

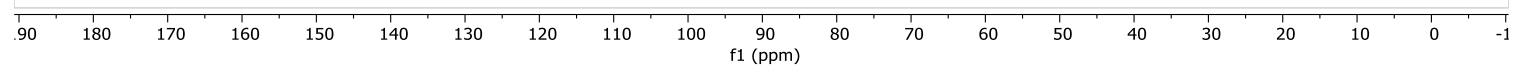



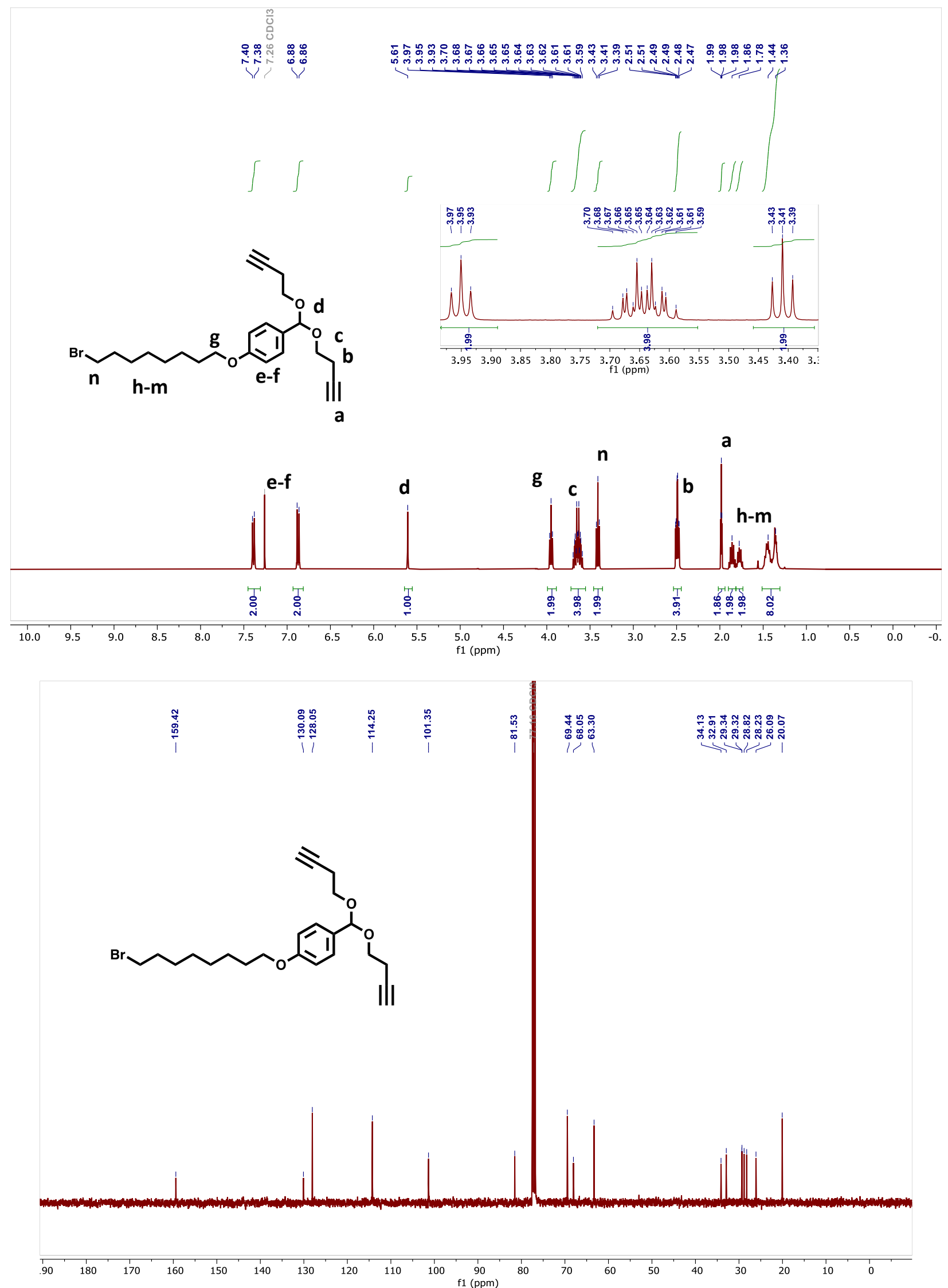

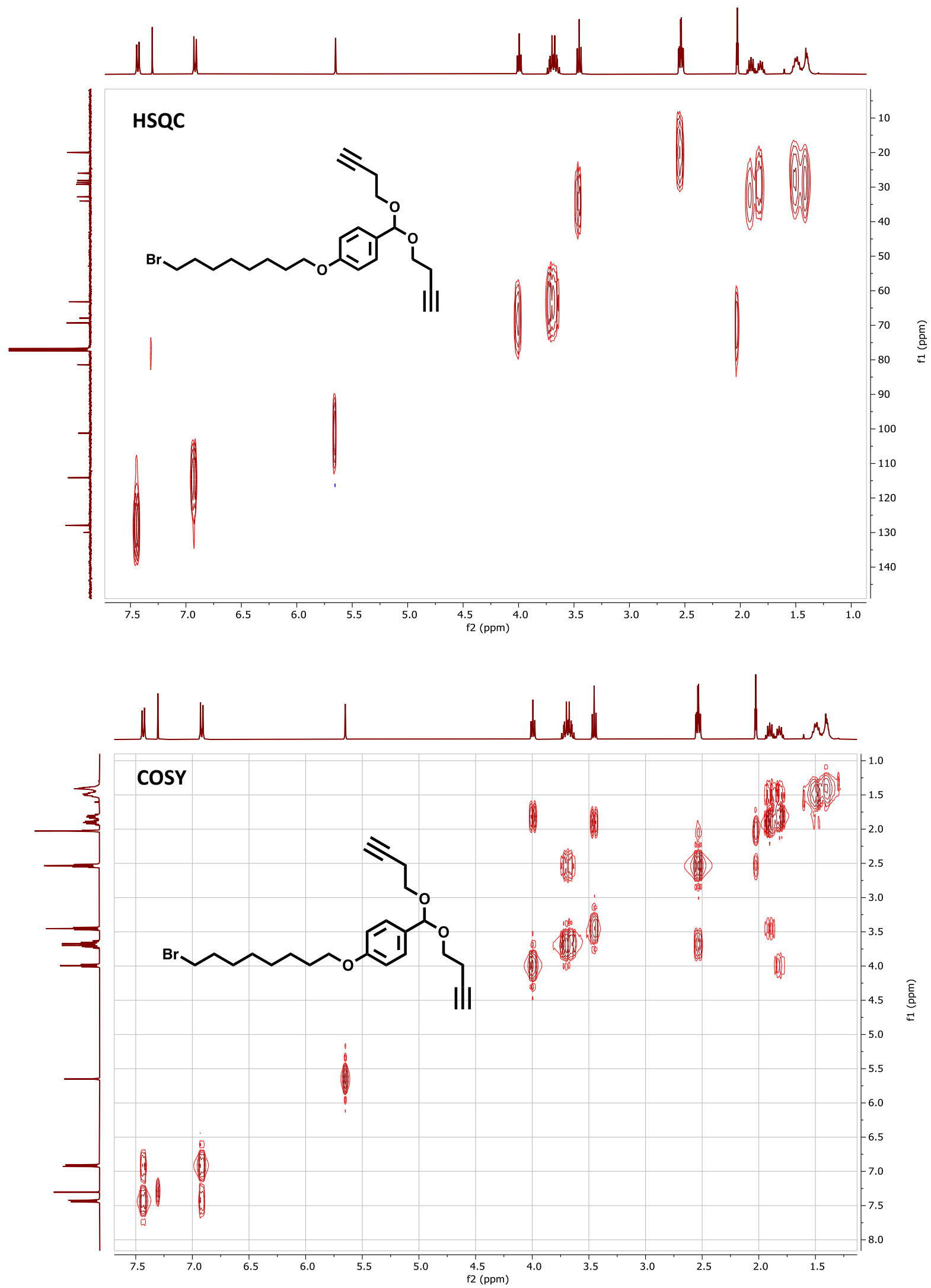


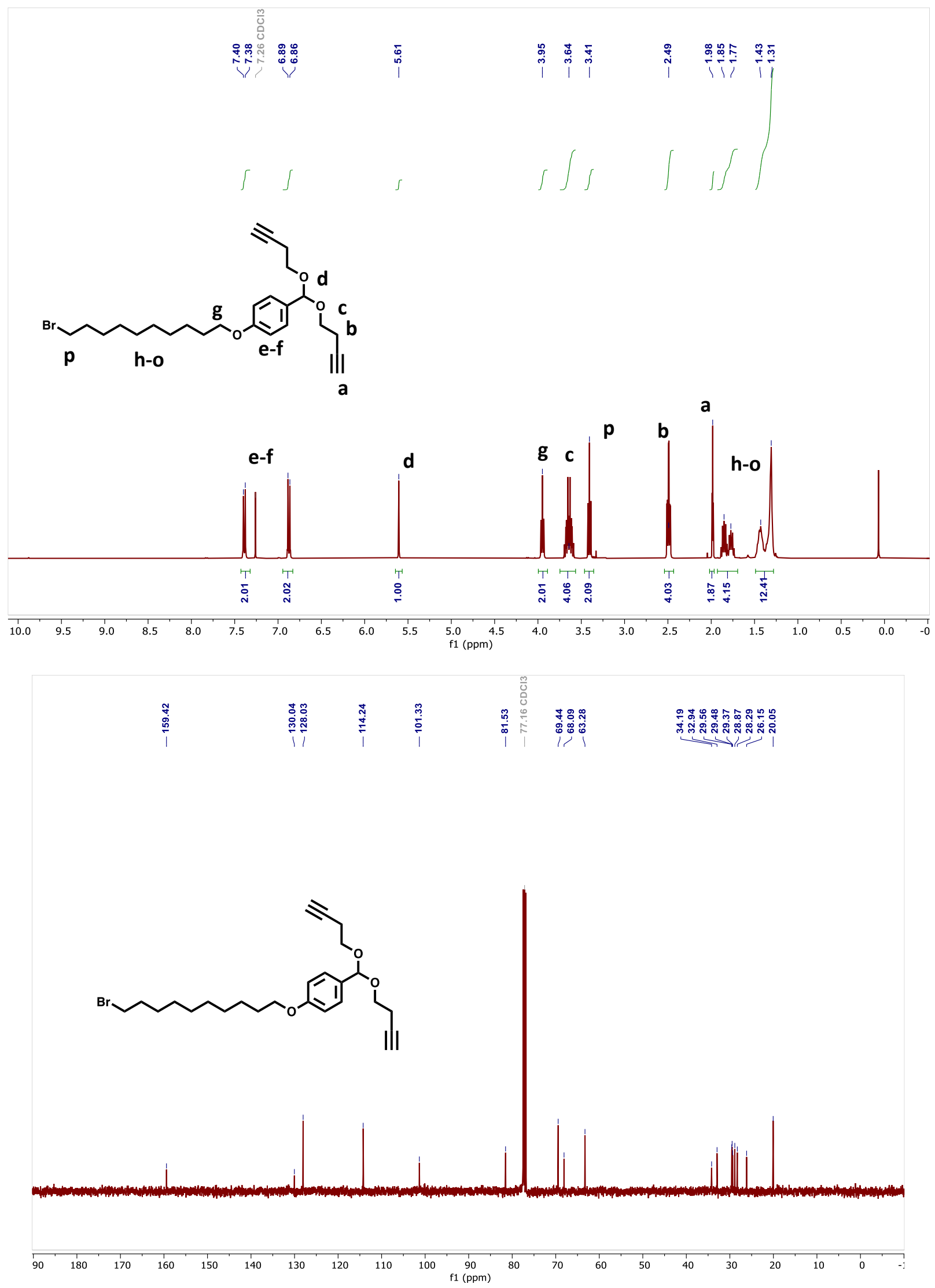



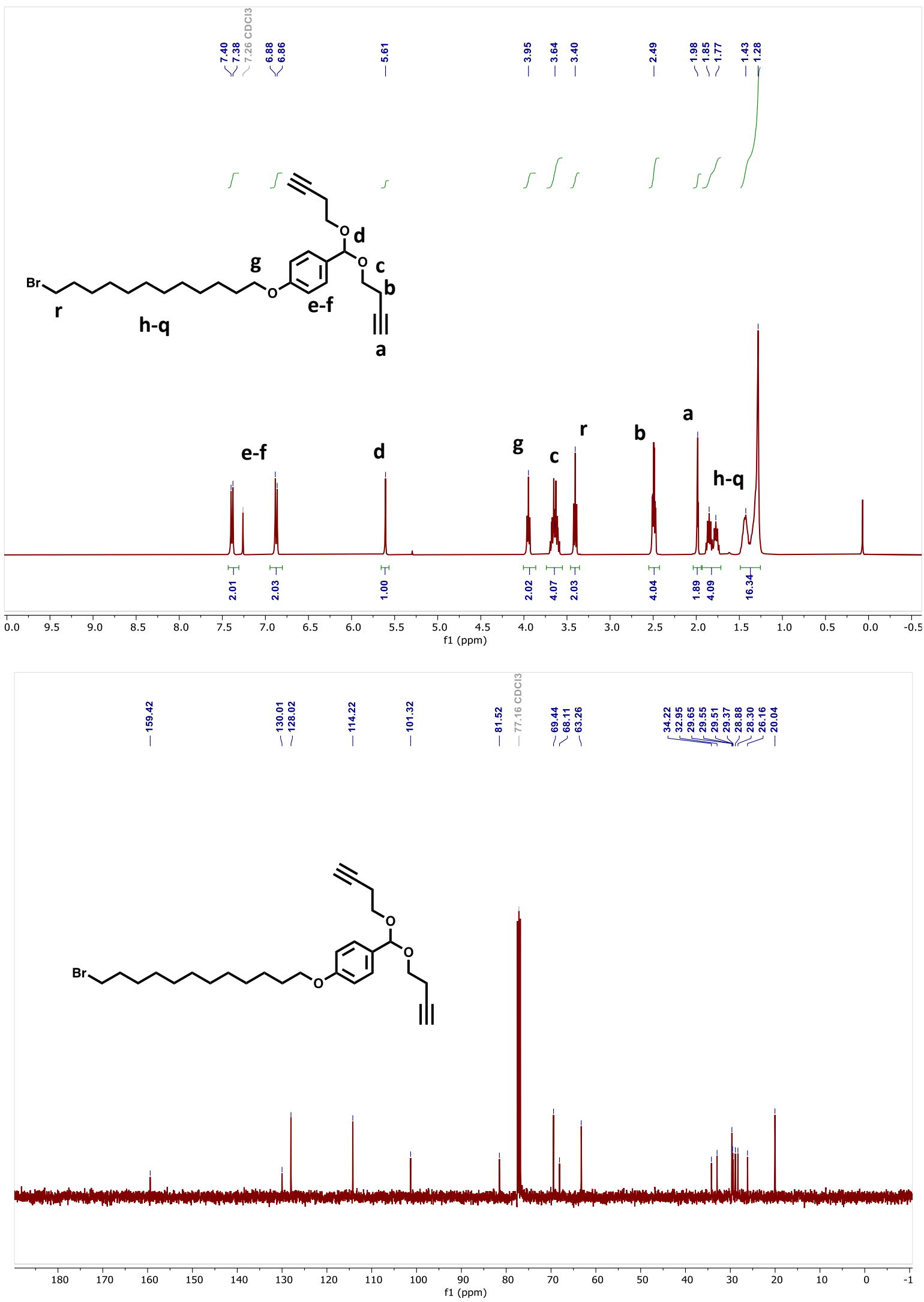

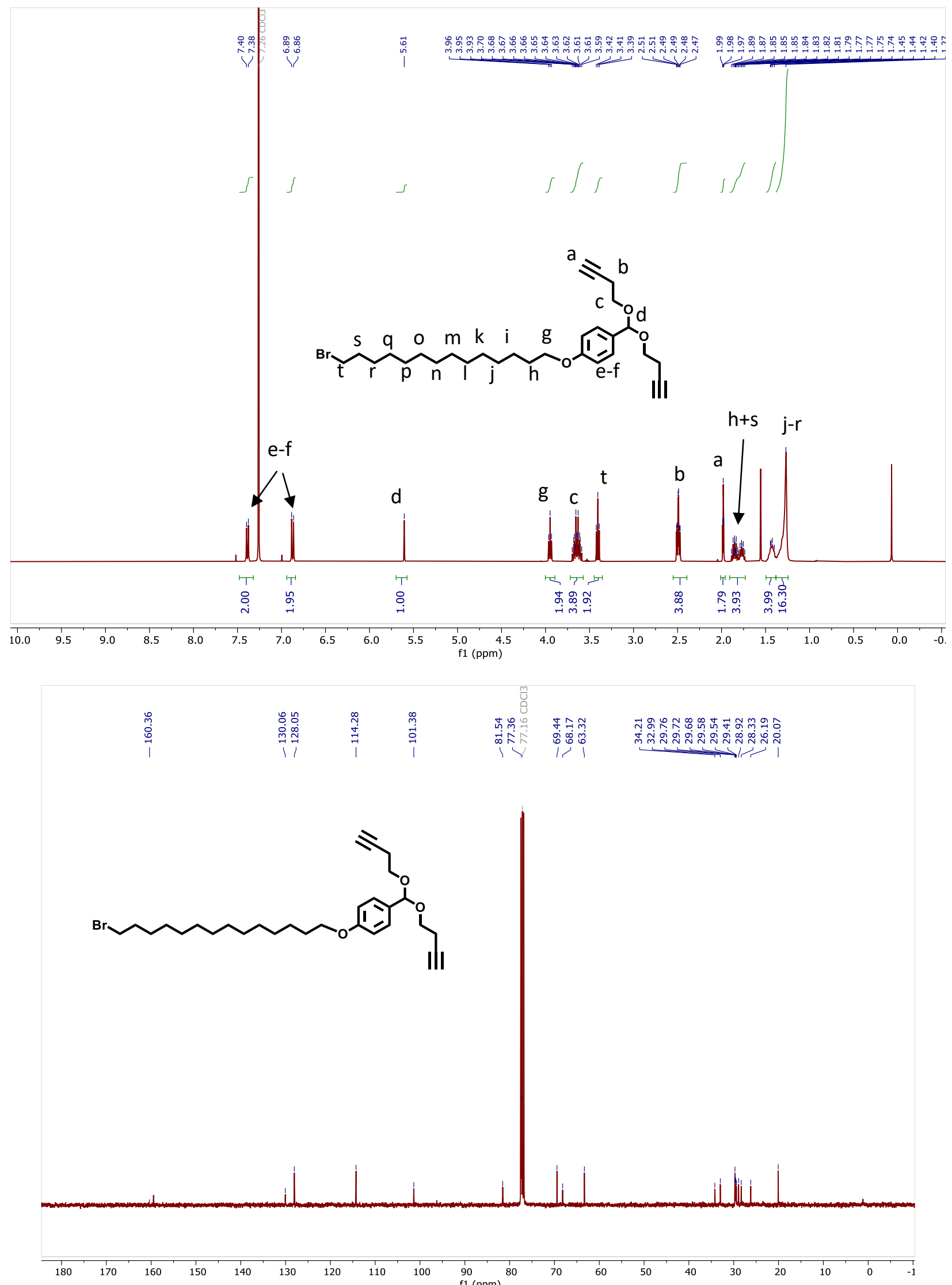

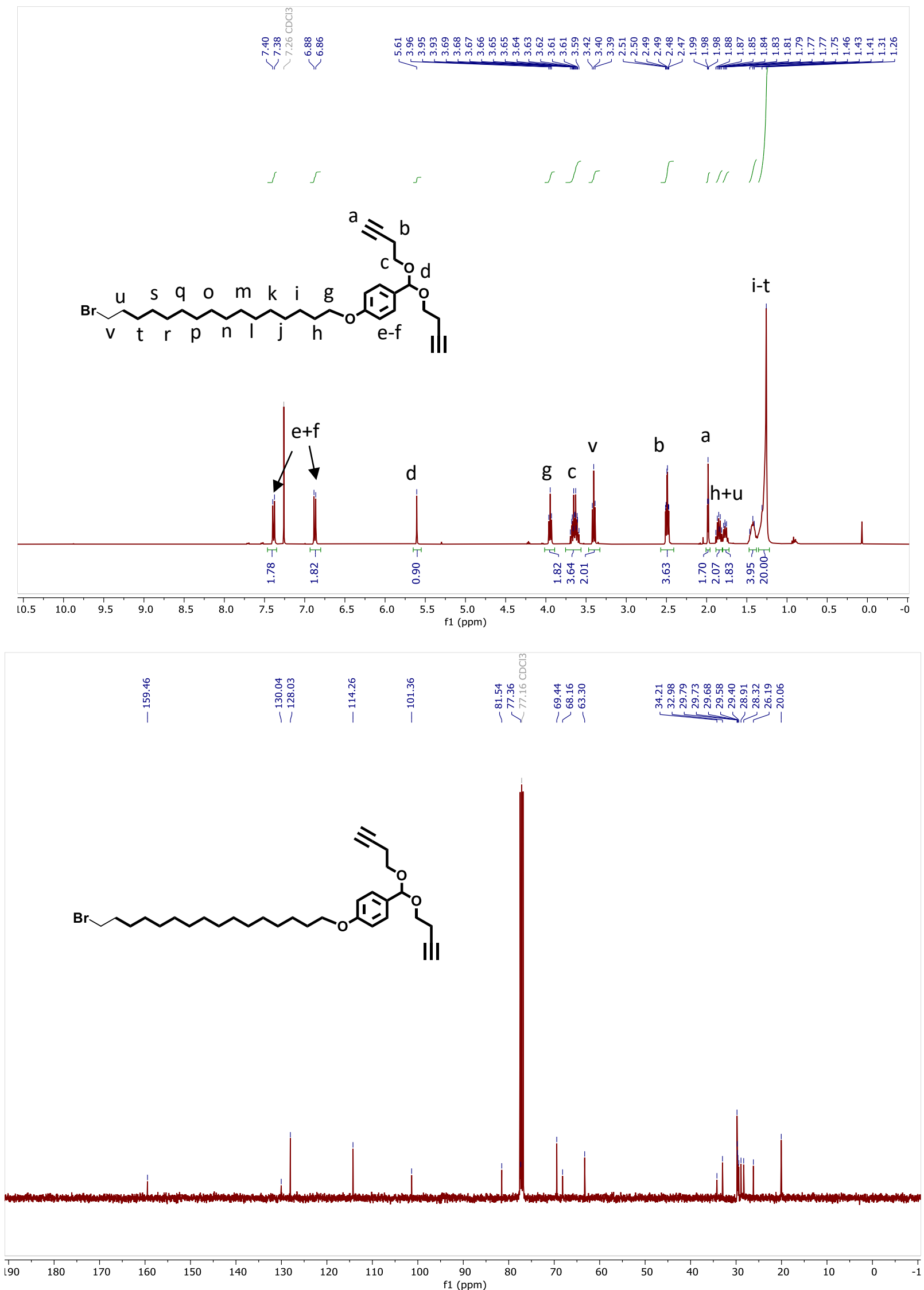

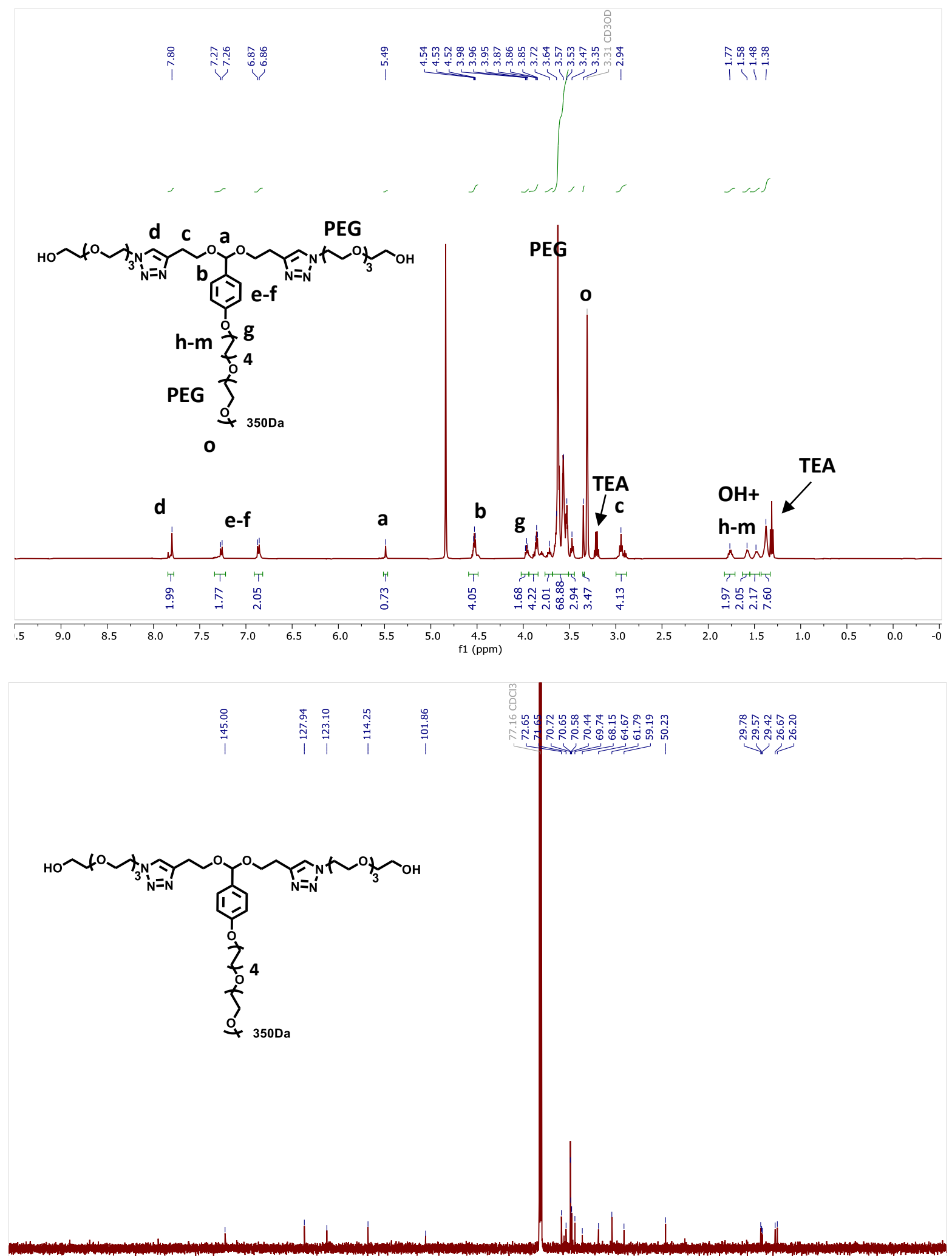

$\begin{array}{lllll}190 \quad 180 & 170 & 160 & 150\end{array}$

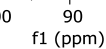




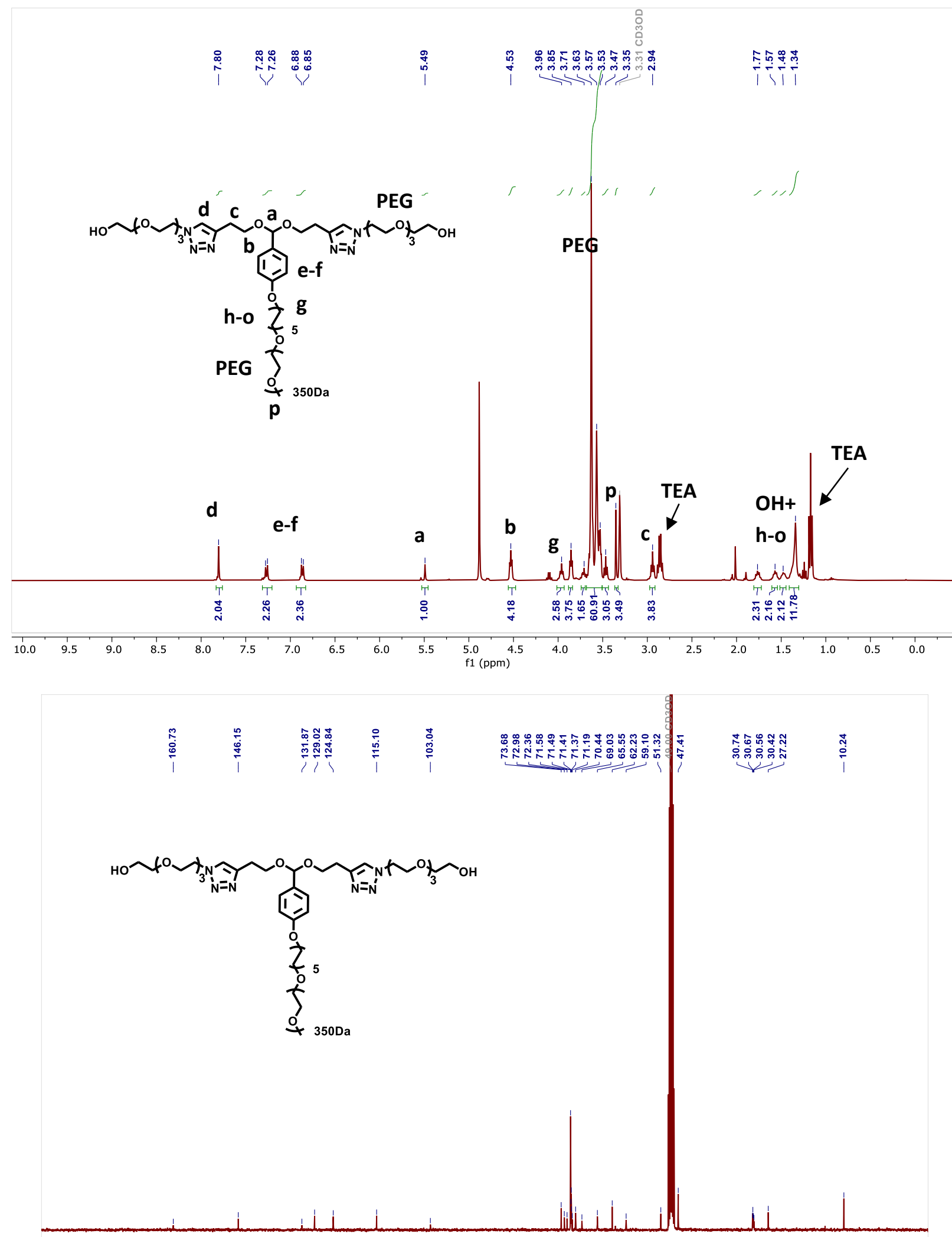

\begin{tabular}{lllllllllllllllllllll}
\hline 90 & 180 & 170 & 160 & 150 & 140 & 130 & 120 & 110 & 100 & 90 & 80 & 70 & 60 & 50 & 40 & 30 & 20 & 10 & 0
\end{tabular} 

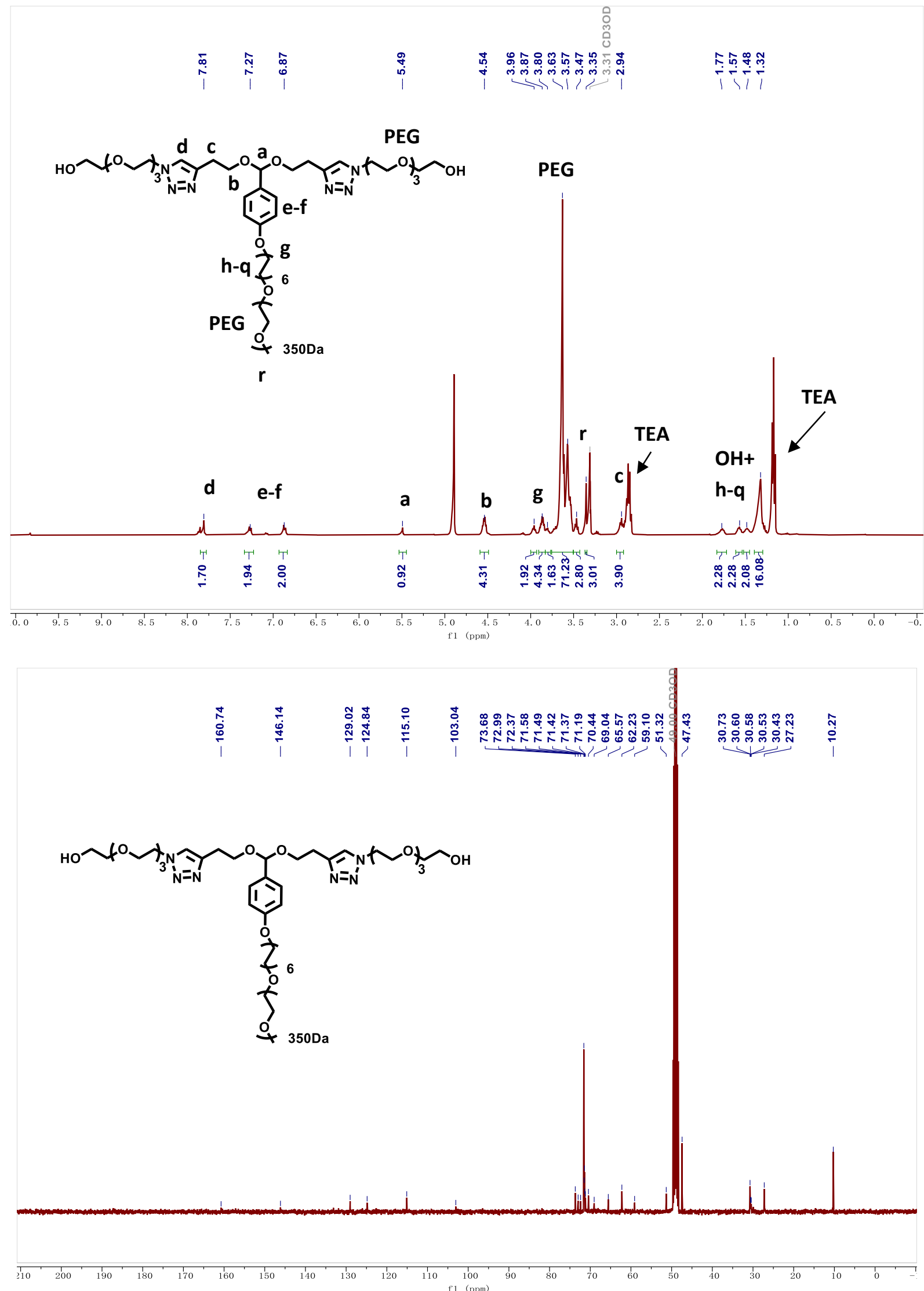


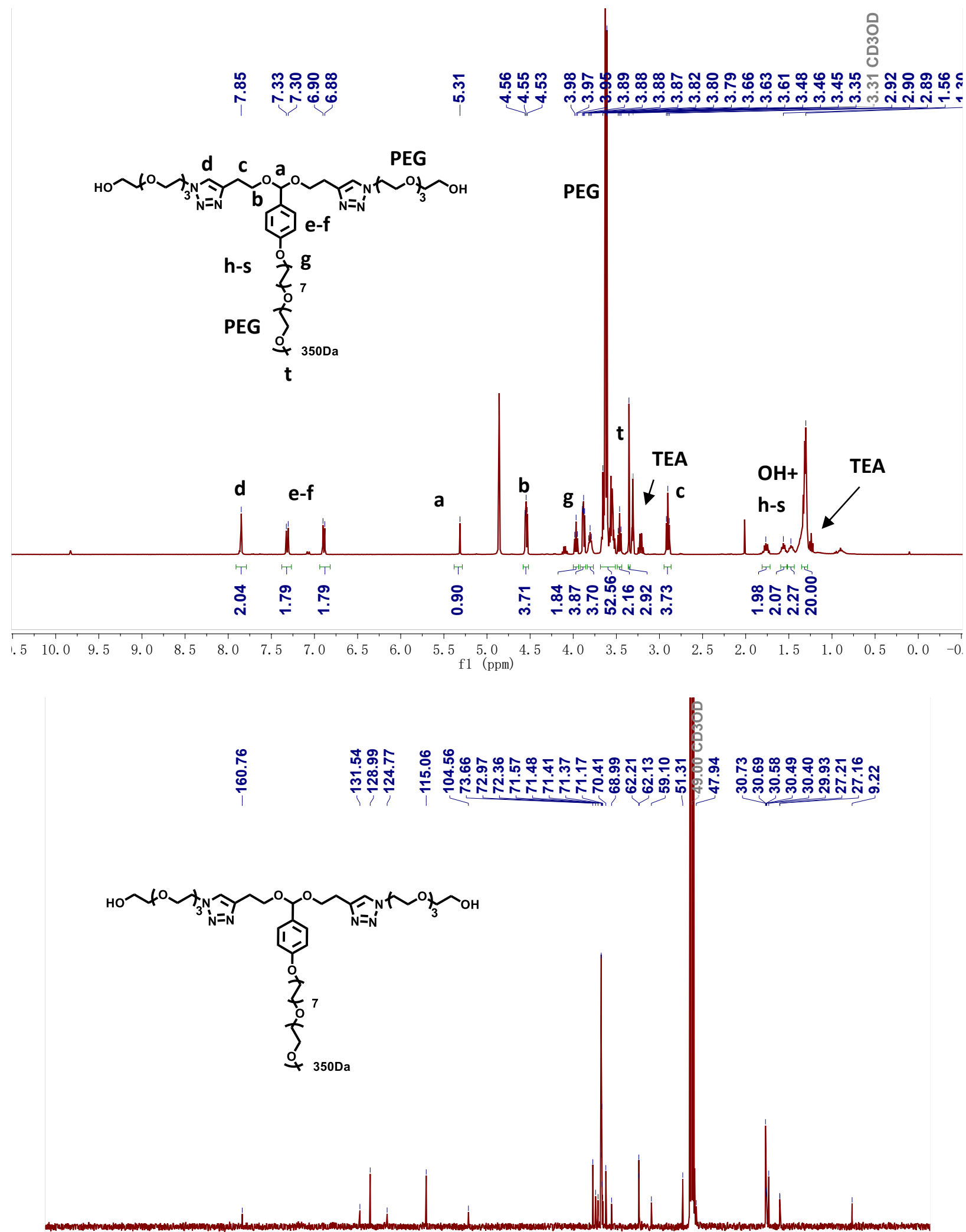

$\begin{array}{lllllllllll}200 & 190 & 180 & 170 & 160 & 150 & 140 & 130 & 120 & 110 & 100 \\ \mathrm{f} 1 & (\mathrm{ppm})\end{array}$ 


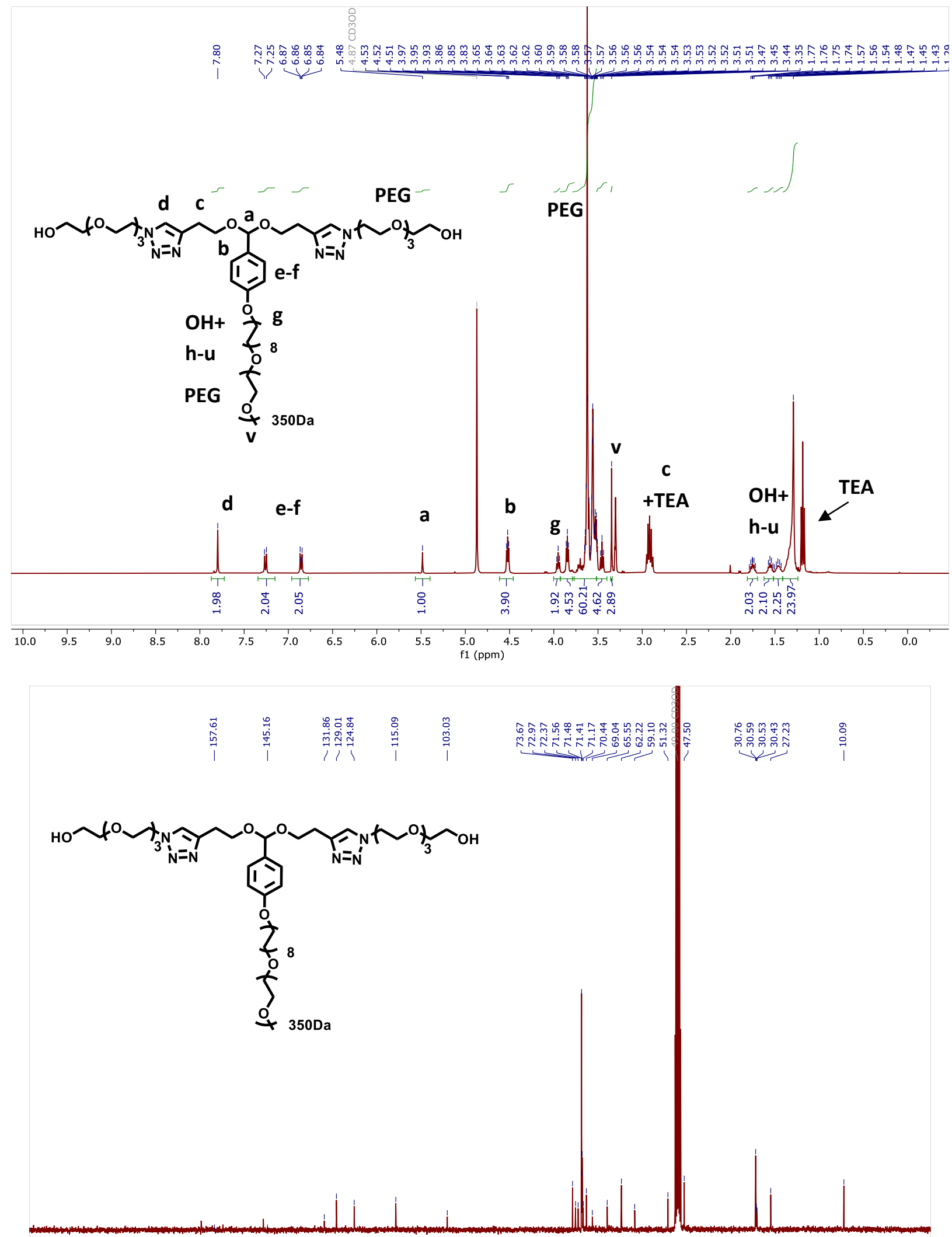

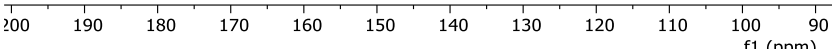




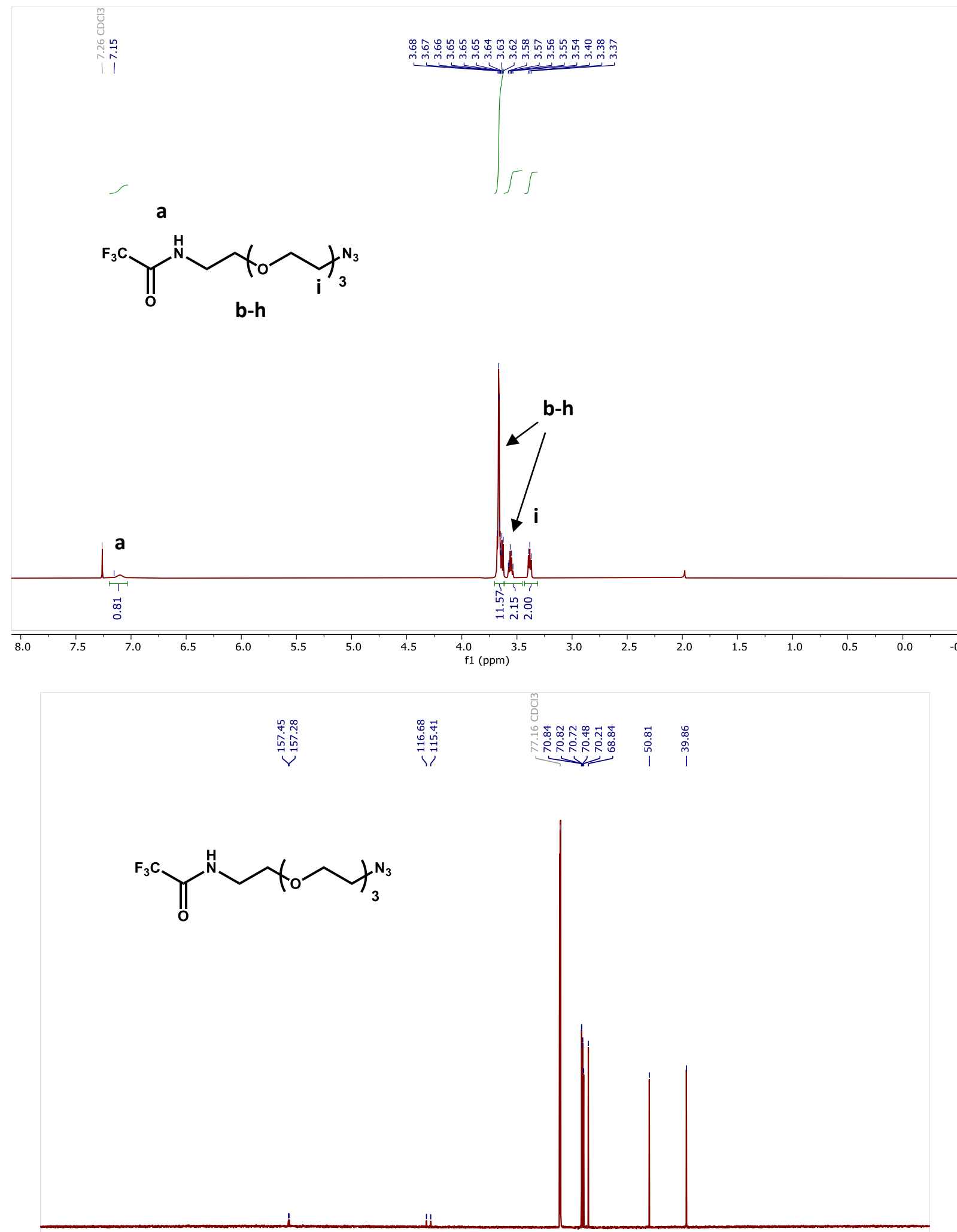

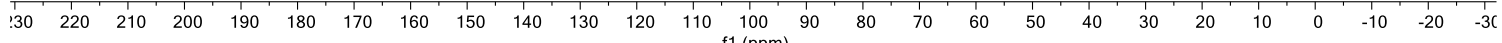



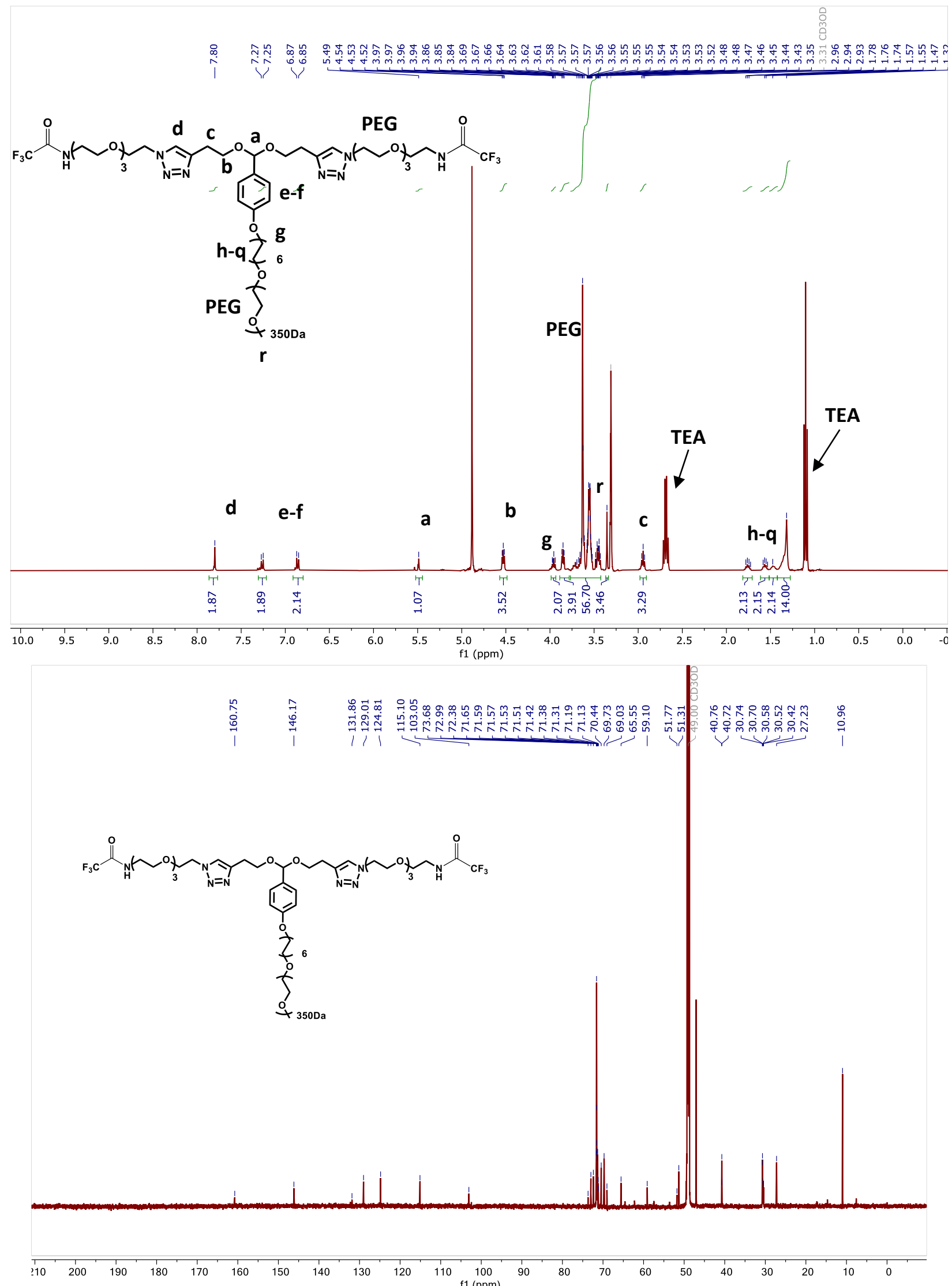


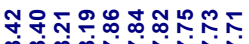

舟<smiles>C#CC(C)CC</smiles>

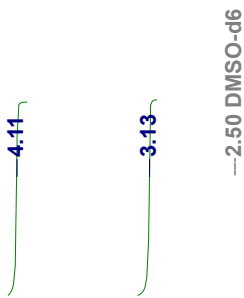<smiles>CSc1sc2ccccc2[n+]1C</smiles>

$\mathbf{I}^{-}$

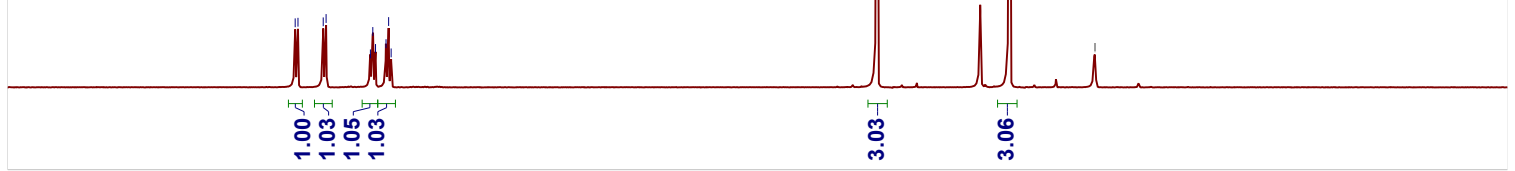

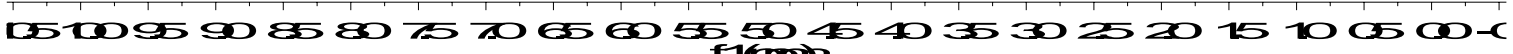
F1कpoid
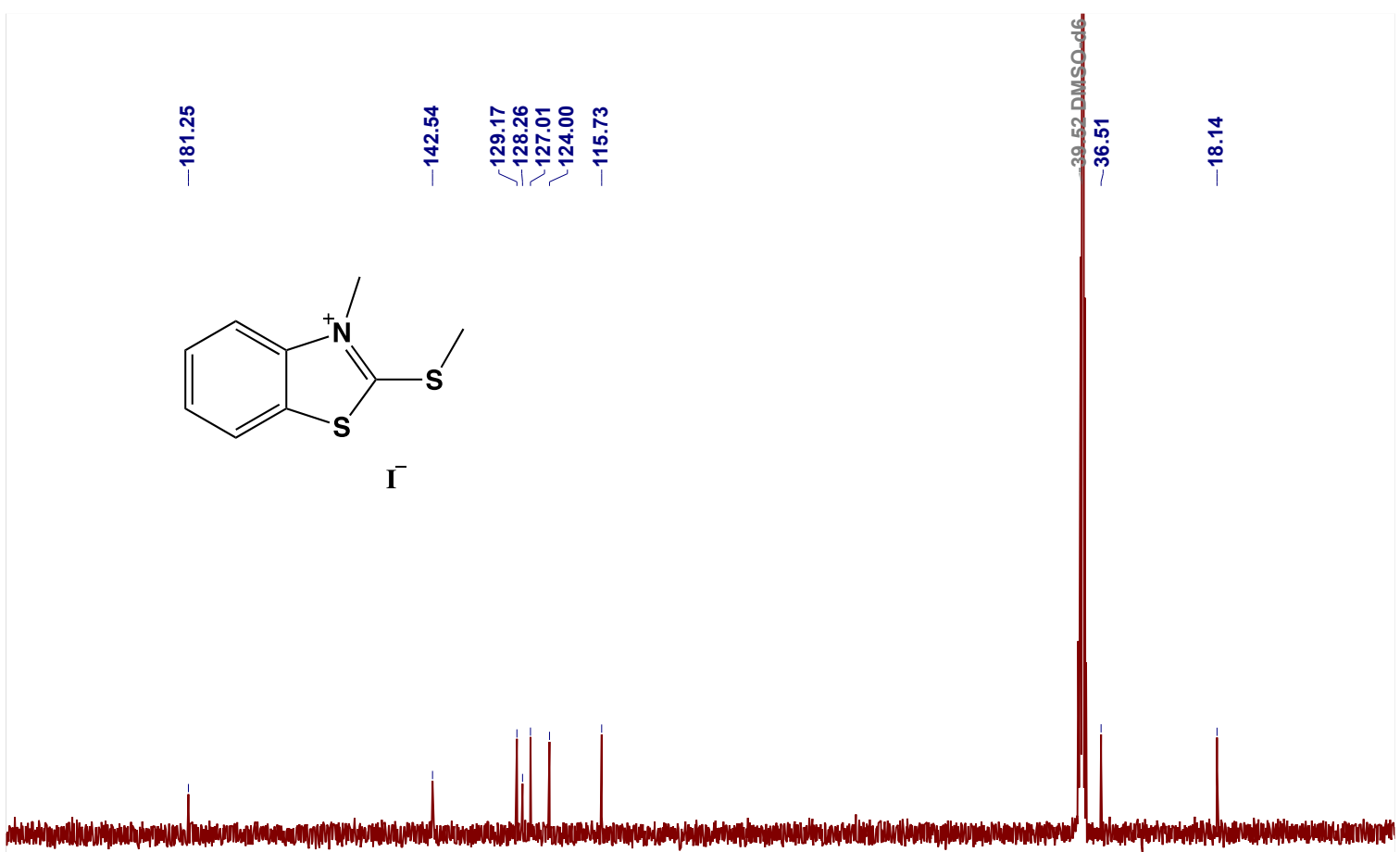

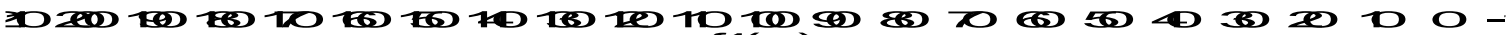
F1क्ण 

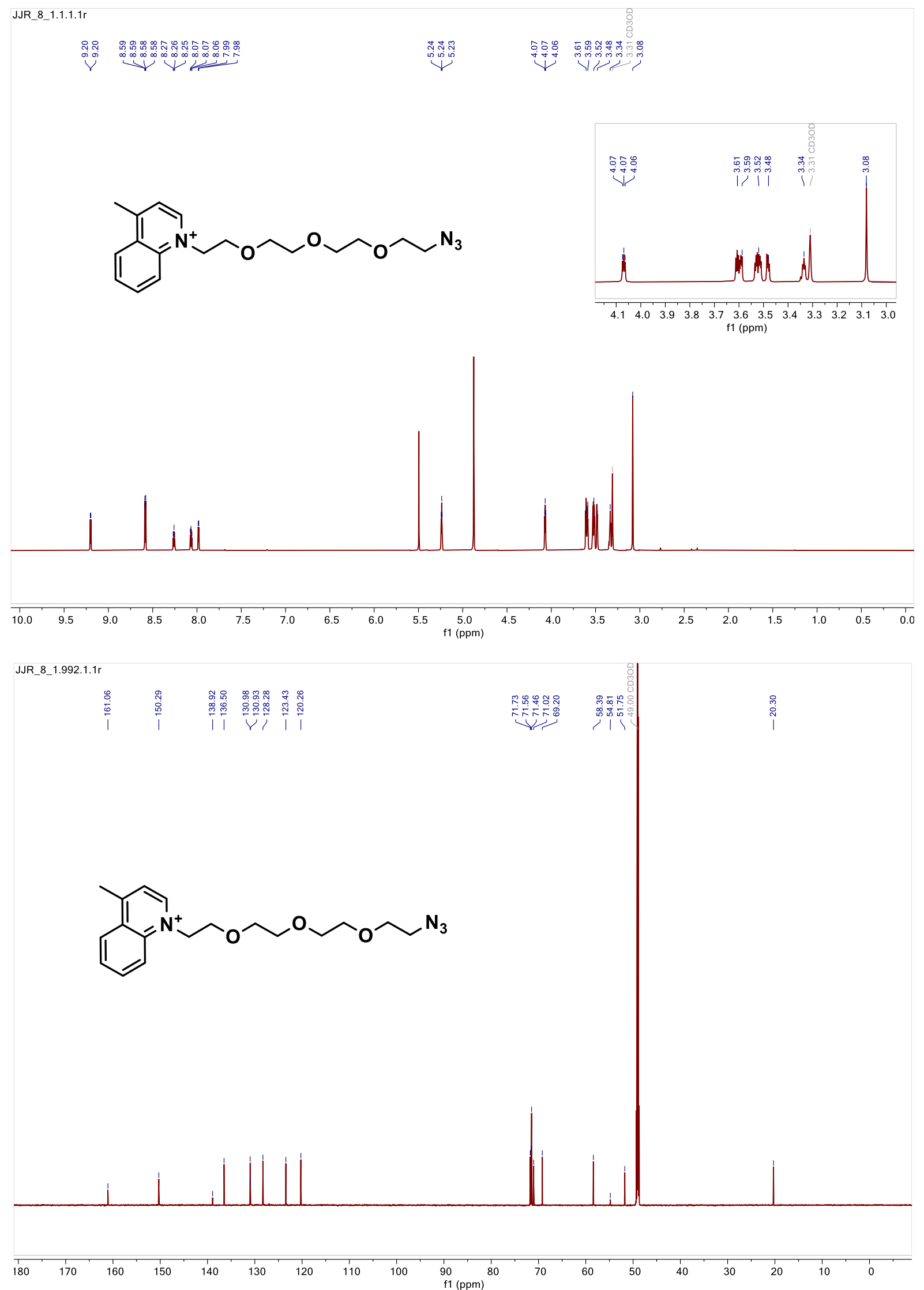

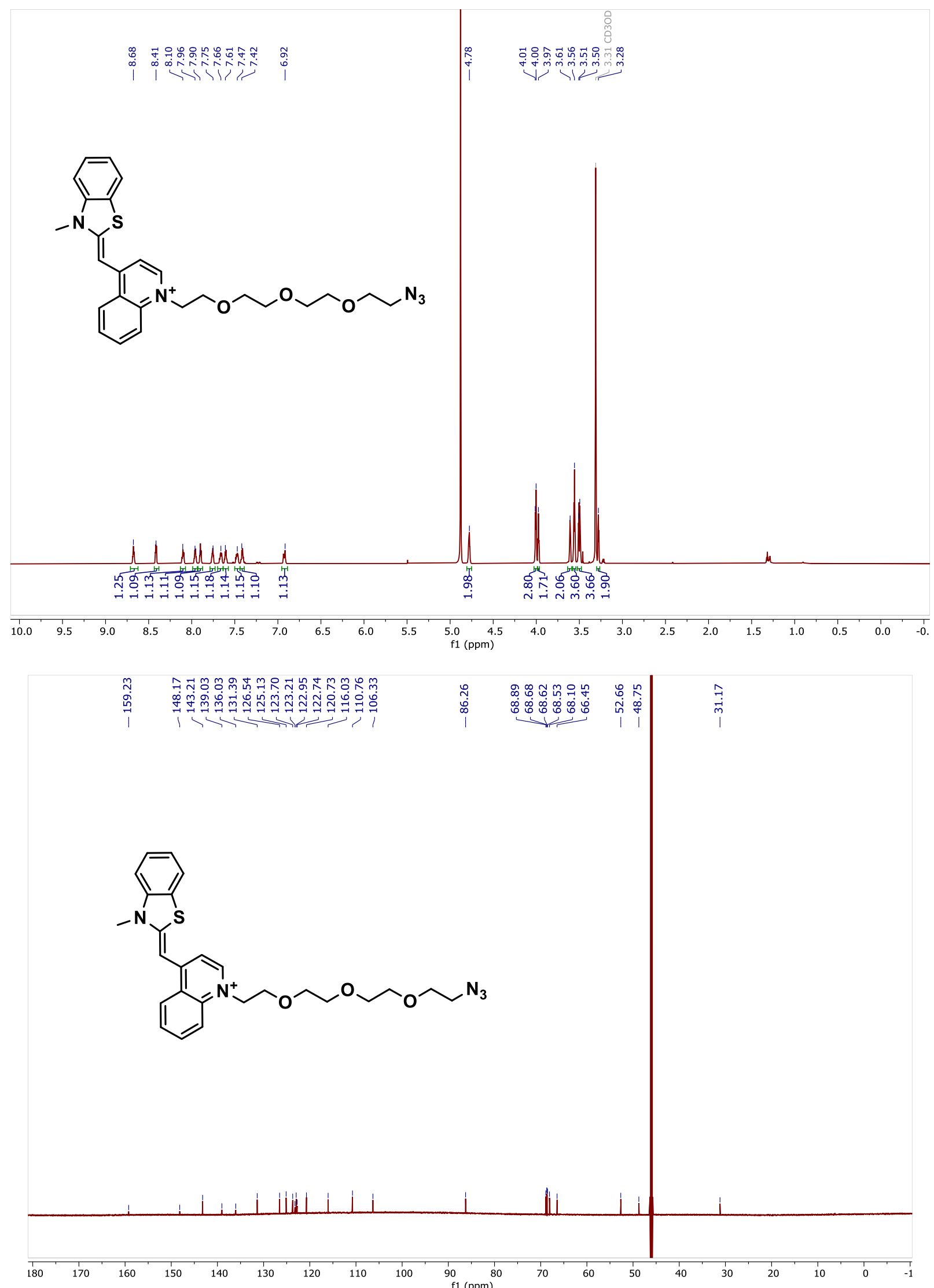

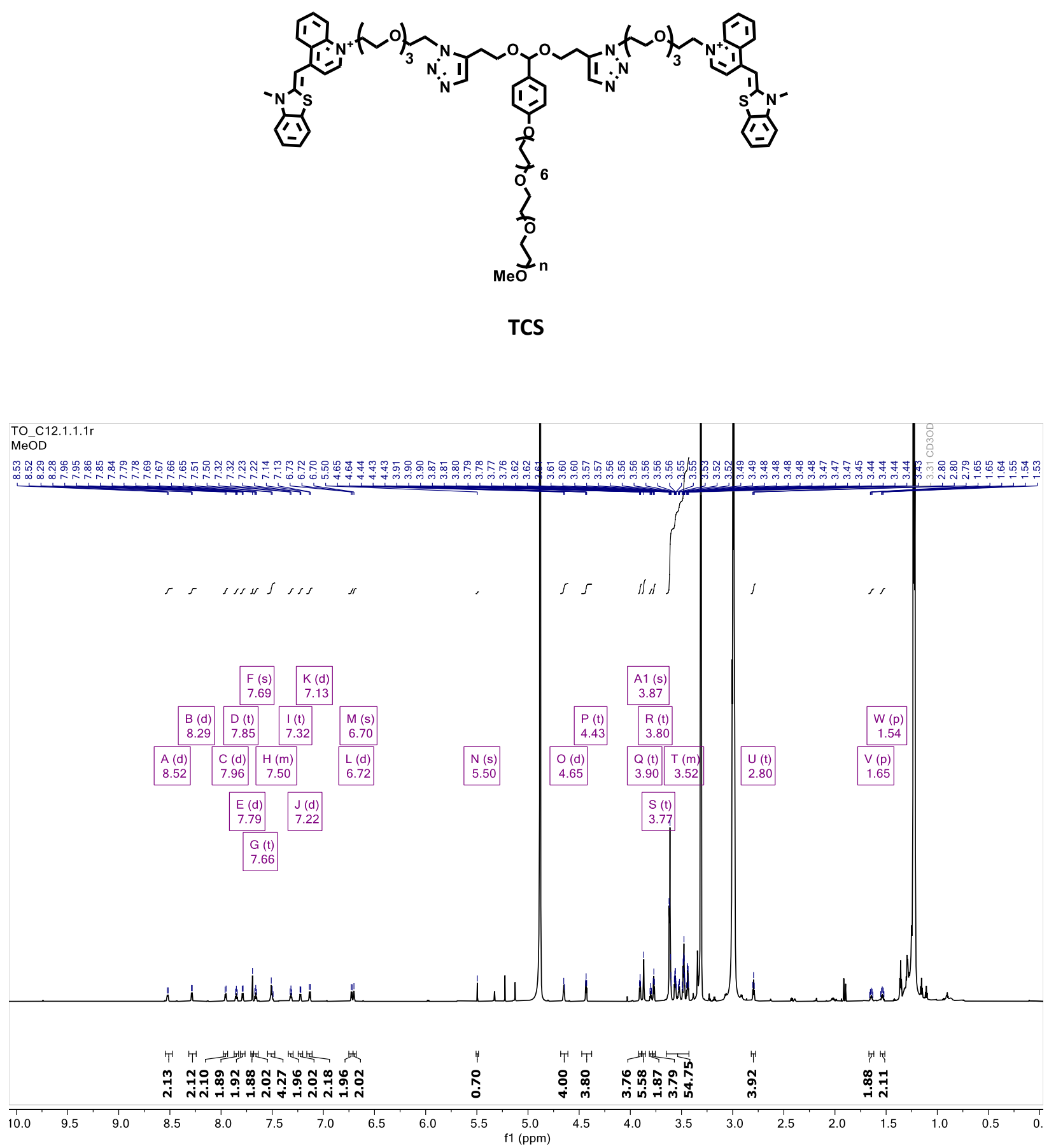

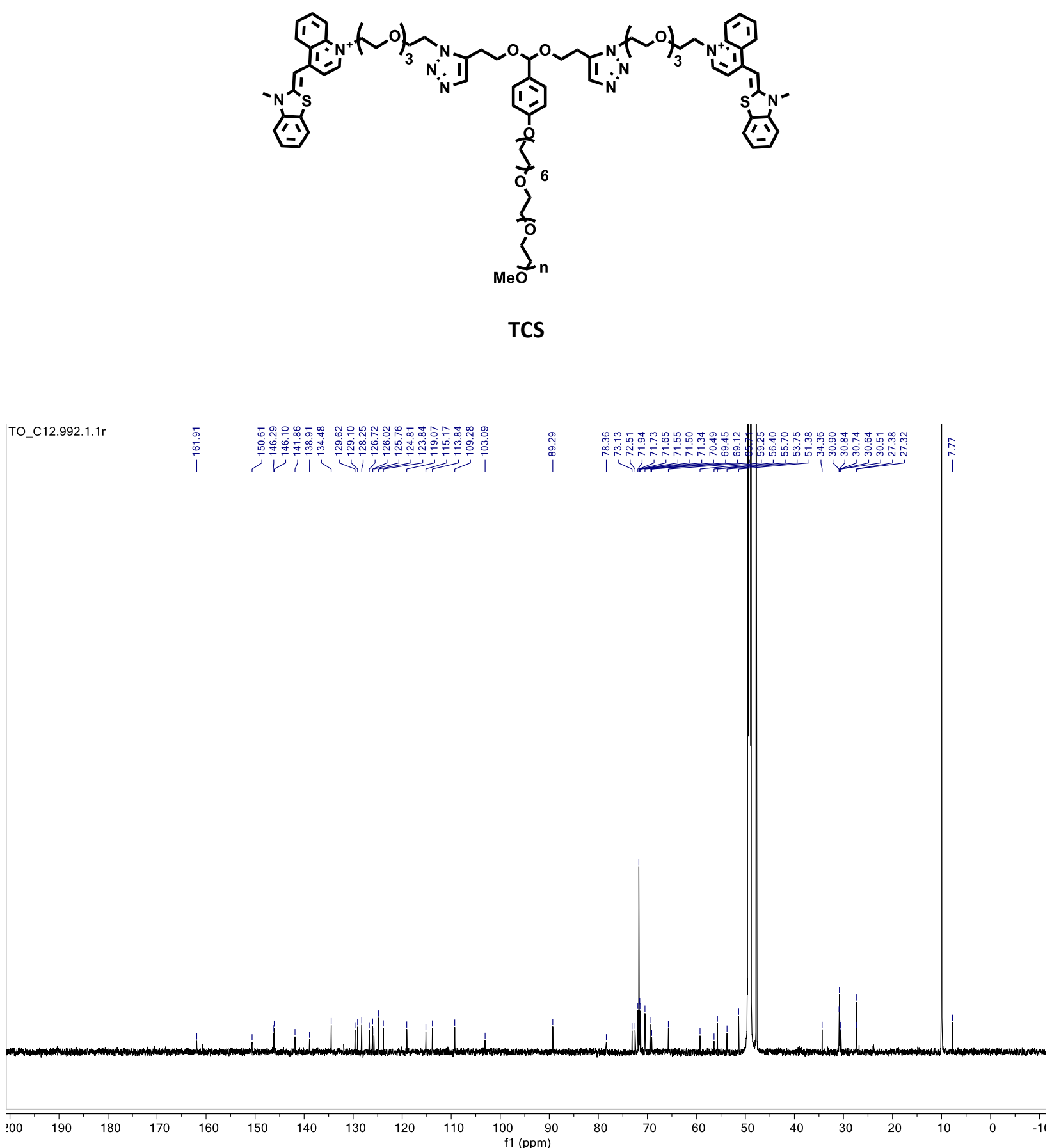


\section{Citations}

1 ChemAxon, Marvin, 2019.

2 K. Vanommeslaeghe, E. Hatcher, C. Acharya, S. Kundu, S. Zhong, J. Shim, E. Darian, O. Guvench, P. Lopes, I. Vorobyov and A. D. Mackerell, J. Comput. Chem., 2010, 31, 671-690.

3 W. Yu, X. He, K. Vanommeslaeghe and A. D. MacKerell, J. Comput. Chem., 2012, 33, 2451-2468.

4 K. Vanommeslaeghe and A. D. MacKerell, J. Chem. Inf. Model., 2012, 52, 3144-3154.

5 K. Vanommeslaeghe, E. P. Raman and A. D. MacKerell, J. Chem. Inf. Model., 2012, 52, 3155-3168.

6 N. M. O’Boyle, M. Banck, C. A. James, C. Morley, T. Vandermeersch and G. R. Hutchison, J. Cheminformatics, 2011, 3, 33.

7 Schrödinger, LLC, The PyMOL Molecular Graphics System, 2019.

8 H. J. C. Berendsen, J. P. M. Postma, W. F. van Gunsteren, A. DiNola and J. R. Haak, J. Chem. Phys., 1984, 81, 3684-3690.

9 M. Parrinello and A. Rahman, J. Appl. Phys, 1981, 52, 7182-7190.

10 W. Humphrey, A. Dalke and K. Schulten, J. Mol. Graph., 1996, 14, 33-38.

11 D. Vercauteren, R. E. Vandenbroucke, A. T. Jones, J. Rejman, J. Demeester, S. C. De Smedt, N. N. Sanders and K. Braeckmans, Molecular Therapy, 2010, 18, 561-569.

12 G. J. Doherty and H. T. McMahon, Annual Review of Biochemistry, 2009, 78, 857-902.

13 S. Cui, S. Zhang, H. Chen, B. Wang, Y. Zhao and D. Zhi, ENG, 2012, 04, 172-175.

14 P. Lajoie and I. R. Nabi, Journal of Cellular and Molecular Medicine, 2007, 11, 644-653.

15 J. ter Maat, R. Regeling, C. J. Ingham, C. A. G. M. Weijers, M. Giesbers, W. M. de Vos and H. Zuilhof, Langmuir, 2011, 27, 13606-13617. 